UDC 930.26(470.46):391

LBC 63.48(235.4)-417

\title{
A PRECIOUS BELT SET FROM THE NOMADIC ELITE BURIAL NEAR THE VILLAGE OF KOSIKA
}

\author{
Mikhail Yu. Treister \\ German Archaeological Institute, Berlin, Germany
}

\begin{abstract}
The paper is devoted to the study of the belt set (a buckle and a belt tip made of gold in the form of hedgehogs with inlays of color stone, glass, paste and with the use of cloisonné technique) from the ruined elite burial of the Middle Sarmatian time, discovered in 1984 in the Baer ridge near the village of Kosika in the Lower Volga region. The author comes to the conclusion that the elements of this belt set were designed especially for a nomad originating from Eastern Eurasia. According to the original idea, which was probably represented on the buckle and on the belttip from the Siberian collection, the hedgehog was only one of the heroes of the plot, who had rendered harmless the snakes biting the griffins. Later the idea was changed, and the hedgehog was now represented as a winner, with strangled snakes tied in form of the Herakles knot behind his back and reduced images of griffins depicting only their heads. The elements of decoration and castes images, peculiar of the Late Hellenistic jewelry, were inserted in the composition. Instead of the inlays of turquoise, typical for the buckles of Chinese, Central Asian and Parthian origin, those of garnets, glass and paste were used. Taking into account all these observations, it is logical to assume the fabrication of elements of the belt set from the village of Kosika in a highly specialized toreutic workshop. This was most likely to occur in the second half of the $2^{\text {nd }}-1^{\text {st }} \mathrm{cc}$. BC in Iran or in Asia Minor. Taking into account the unique structure and design of belt elements, as well as their high material value, we can assume that the belt was a statusmarking object and perhaps even a symbol of the royal power.

Key words: Middle Sarmatian culture, elite burials, Kosika, Lower Volga region, Parthia, Iran, Asia Minor, Siberian Collection, images of hedgehog and snake in ancient art, belt set, Hellenistic toreutics and jewelry.
\end{abstract}

Citation. Treister M.Yu., 2018. A Precious Belt Set from the Nomadic Elite Burial near the Village of Kosika. The Lower Volga Archaeological Bulletin, vol. 17, no. 1, pp. 108-143. (in Russian).

УДК 930.26(470.46):391

ББК 63.48(235.4)-417

\section{ДРАГОЦЕННЫЙ ПОЯСНОЙ НАБОР ИЗ ЭЛИТНОГО ПОГРЕБЕНИЯ КОЧЕВНИКА У с. КОСИКА}

\author{
Михаил Юрьевич Трейстер \\ Германский археологический институт, г. Берлин, Германия
}

\begin{abstract}
Аннотация. Статья посвящена публикации поясной пряжки и наконечника пояса, выполненных в форме ежей из золота со вставками цветного камня, стекла и пасты и с использованием техники клуазоне, из разрушенного элитного погребения среднесарматского времени, открытого в 1984 г. в бугре Бэра у с. Косика в Нижнем Поволжье. Автор приходит к выводу, что элементы этого поясного гарнитура создавались специально для кочевника, выходца из Восточной Евразии. Изначальная концепция, которая, вероятно, была представлена 作 ными им змеями, завязанными «узлом Геракла» за его спиной и редуцированными изображениями грифо$\sum$ нов, сокращенных до головок. В композицию были введены элементы декора и конструкции кастов, характер气 ные для позднеэллинистического ювелирного дела. Вместо характерных для пряжек китайского, центральноазиатского и парфянского происхождения вставок бирюзы были использованы вставки граната, стекла и пасты. С С учетом всех этих наблюдений логично предположить изготовление элементов поясной гарнитуры из Косики () в высокоспециализированной мастерской торевта. С наибольшей вероятностью это могло произойти во вто-
\end{abstract}


рой половине II - I в. до н.э. в Иране или в Малой Азии. Пояс, к которому относились публикуемые пряжки, учитывая их уникальное конструктивное и художественное исполнение, а также, безусловно, высокую материальную ценность, был статусным предметом и возможно даже инсигнией царской власти.

Ключевые слова: среднесарматская культура, элитные погребения, Косика, Нижнее Поволжье, Парфия, Иран, Малая Азия, Сибирская коллекция, образы ежа и змеи в древнем искусстве, поясной набор, эллинистическая торевтика и ювелирное дело.

Цитирование. Трейстер М. Ю., 2018. Драгоценный поясной набор из элитного погребения кочевника у с. Косика // Нижневолжский археологический вестник. Т. 17, № 1. С. 108-143.

\section{1. Контекст находки}

Погребение в бугре Бэра (длинной возвышенности, перпендикулярной Волге) у с. Косика Енотаеевского района было открыто и разрушено в 1984 г. во время прокладки водопроводной траншеи вдоль шоссе Москва Астрахань в 111 км к северу от Астрахани. Большая часть вещей из центральной части погребения, практически полностью разрушенной роторным экскаватором, попали строителям и позднее частично были переданы Поволжской археологической экспедиции, а само погребение было доследовано в том же году. В статьях, опубликованных в конце 1980-х первой половине 1990-х гг. [Дворниченко, Федоров-Давыдов, 1989 , с. 5-13; 1993, с. 141179; Dvornitchenko, Fedorov-Davydov, 1994, p. 66-75], был дан общий обзор находок и опубликованы работы, посвященные серебряным сосудам из погребения [Трейстер, 1994, с. 172 203; Treister, 2005, p. 199-255] и надписи на венчике серебряного таза [Виноградов, 1994, c. 151-170]. Со времени этих публикаций прошло почти 25 лет. Вопросы, связанные с датировкой и интерпретацией погребения и отдельных находок, с тех пор неоднократно поднимались в самых разных работах ${ }^{1}$, но публикаций отдельных находок из Косики, основанных на работе de visu с памятниками, не было - таким образом, дискуссия об одном из важнейших элитных погребений среднесарматского периода ведется практически на основании обзорной статьи, а интерпретации по существу давно живут своей жизнью, оторванной от реального археологического материала.

Автор впервые получил возможность работать с находками из Косики в 1989 1990 гг. благодаря приглашению В.В. Дворниченко, когда часть из них хранилась в Москве в Институте археологии. Данная публикация, ставящая задачу хотя бы частично ликвиди- ровать пробелы в информации и основанной на изучении находок из Косики интерпретации, базируется на работе в фондах и экспозиции Астраханского государственного объединенного историко-архитектурного музея-заповедника в рамках совместного германско-российского проекта в сентябре 2015 года ${ }^{2}$.

\section{2. Описание пряжки и наконечника пояса}

Выполненные в одном стиле пряжка и наконечник пояса имеют близкую пятиугольную форму с параллельными длинными сторонами, прямой - передней и подтреугольной задней боковыми сторонами и представляют собой выполненное в высоком рельефе и помещенное на невысоком цоколе изображение лежащего ежа с вытянутыми вперед передними лапками, которого обвивают по бокам и сзади две змеи, образующие сзади ежа «гераклов узел». Спереди в углах помещено по головке грифона, между которыми по центру передней боковой стороны расположены шпеньки - с округлой головкой на наконечнике ремня и с каплевидной - на пряжке; оба со вставками граната. Пряжка отличается от наконечника ремня тем, что у нее имеется отверстие для продевания ремня неправильной овальной формы, расположенное в передней части между мордочкой ежа и рамкой со шпеньком. Композиции двух предметов выполнены в зеркальной симметрии (рис. 1-6).

Конструктивно и пряжка, и наконечник пояса исполнены одинаково (рис. 1) и образованы: 1) верхней пластиной с рельефным изображением и припаянными к ним с оборотной стороны четырьмя пластинчатыми петлями (рис. 4,1,3, 6,1,3); 2) впаянным в ее центральной части с оборотной стороны вместилищем овальной в плане формы со стенками, плавно сужающимися кверху (рис. 3,2, 4,3, 5,2, 6,3). 
Место соединения верхней рельефной пластины и вместилища оформлено горизонтальным плоским краем, образующим овальное отверстие. Снизу вместилище имеет ровное горизонтальное дно с расположенным в центре отверстием прямоугольной формы. В это отверстие вставлена вертикально полая трубка прямоугольного сечения со скругленными углами (рис. 4,1, 6,1). Внизу край трубки выступает чуть ниже дна вместилища, вверху чуть выше горизонтального края овального отверстия. С внутренней стороны дно вокруг вместилища на пряжке укреплено округлой пластиной-шайбой. 3) Спинка ежа представляет собой съемный выпуклый элемент неправильно-овальной в плане формы [та ее часть, которая обращена к голове ежа, оформлена подтреугольным выступом (рис. 2,2, 4,2)]. Снизу съемная часть имеет вертикальную закраину, точно подогнанную под контур отверстия, в которое она входила. В центре съемной части с внутренней стороны впаян вертикальный штифт прямоугольного сечения с округлым отверстием внизу, вставлявшийся в отверстие трубки-приемника вместилища (рис. 4,2 слева, рис. 6,2 слева). Отверстие служило для запирания съемной части при помощи пропущенной через него и под дном вместилища чеки, которые не сохранились. На наконечнике пояса крепление штифта усилено пластиной подпрямоугольной формы (рис. 6,2 справа).

Не исключено, что шайба округлой формы на дне вместилища пряжки и пластинка подпрямоугольной формы с внутренней стороны съемного элемента - результат ремонта.

Верхняя пластина изготовлена из толстого листа глубокой вытяжкой с последующей дочеканкой деталей с лицевой стороны. Еж изображен лежащим на животе с вытянутыми вперед параллельно мордочке передними лапами, а задние - чуть разведены в сторону. Все лапы - трехпалые. Уши выполнены в форме вычеканенных каплевидных кастов, в одном из которых (на наконечнике пояса) сохранилась вставка стекла бирюзового цвета. Глаза оформлены аналогичными кастами подтреугольной формы, в которых на пряжке (в правом) и на наконечнике ремня (в левом) сохранились выпуклые вставки глухого белого стекла с коричневыми круглыми зрачками в центpe (рис. 2, 3,1, 5,1).
Фигурку ежа по бокам и сзади обрамляют две змеи, завязанные сзади «геракловым узлом». Тела их, перекинутые через задние лапки ежа, свернуты кольцами с каждой стороны между передними и задними лапами, а головки лежат на передних лапах ежа. Шкура змей проработана дуговидными насечками, образующими продольные ряды, а сплющенные листовидные головы проработаны глубокой продольной линией и двумя углубленными овалами, обозначающими глаза (рис. 2, 3,3, 5,3).

В передних углах пряжки и наконечника ремня изображены стилизованные головы грифонов с клювами, обращенными друг к другу. Глаза и уши переданы кастами: глаза - круглыми полупрозрачного зеленоватого стекла (одна из вставок на пряжке - не сохранилась), уши - каплевидными (все утрачены) (рис. 2, 3,1, 5,1).

Выпуклая съемная пластина (спинка ежа) с внешней стороны полностью украшена вставками в кастах, впаянных в ее основание. Ее подтреугольные части, обращенные к головам ежей, украшают крупные каплевидные касты со вставками кабошонов из граната и альмандина. Вся остальная поверхность пластины плотно (практически без свободных мест) заполнена кастами округлой в плане формы со вставками из камней и глухого стекла зеленого, красного, синего, голубого и белого цветов.

Cохранность. 1 (пряжка): утрачены шесть из десяти вставок: из ушей, левого глаза, из гнезд по сторонам лапок и слева от штырька, а также восемь вставок из гнезд на крышке. На поверхности царапины, потертость, небольшие вмятины (рис. 2, 1, 3, 4); 2 (наконечник пояса): утрачены четыре из десяти вставок: из правого глаза и уха, из гнезд по сторонам лапок, а также 25 вставок из гнезд на крышке. На поверхности царапины, потертость, небольшие вмятины (рис. 2,2-3, 5, 6).

Пряжка. Вес 52,99 г (основа - 42,67 г, крышка - 10,32 г). Проба 900. Наконечник. Bec 53,72 г (основа - 42,91 г, крышка - 10,81 г). Проба 920. Пряжка. 7,1 × 3,66 см, толщ. 2,3 см. Штырек крышки: сечение $0,23 \times 0,16 \mathrm{~cm}$, дл. 2,2 см. Наконечник: 7,4 × 3,57 см, толщ. 2,1 см. Штырек крышки: сечение $0,26 \times 1,5$, дл. 2,2 см. 
Хранение. Пряжка - инв. № 35528. Наконечник пояса - инв. № 35529.

Литература: [Дворниченко, Федоров-Давыдов, 1993, с. 172 , рис. 19, с. 173-174; Dvornitchenko, Fedorov-Davydov, 1994, p. 70; Treister, 1997, p. 55, 91, fig. 22; Fedorov-Davydov, 2001, p. 147, no. 9, pls. 29-30; Мордвинцева, 2003, c. 87 , № 55, рис. 22; Treister, 2004b, p. 213, no. 20b; Cat. Rome, 2005, p. 128-129, nos. 7778; Малашев, Дзуцев, 2016, с. 173, рис. 16,2; Mordvintseva, 2016, p. 388, 397, 416, pl. VI,1].

\section{3. Поясной набор и конструкция пряжки}

Очевидно, что конструктивно пряжка и наконечник пояса относятся к большой группе поясных наборов, характерной чертой которых является наличие в сплошном теле пряжки прямоугольной прорези для ремня и вертикального, загнутого шпенька, спереди на рамке пряжки, который служил для фиксации ремня в его отверстии. По форме и по стилистическим особенностям наконечник ремня близок пряжке, но не имеет ни шпенька, ни отверстия для ремня.

У кочевников Евразии пряжки рассматриваемого типа с прорезью для ремня и загнутым шпеньком на рамке появляются не позднее III-II вв. до н.э., вначале в форме круглых или восьмерковидных рамок с такими шпеньками [Мошкова, 1960, с. 293-299, рис. 1; Скрипкин, 1990, с. 97-98, тип 1-2, рис. 22,2226; Клепиков, 2002, с. 80-81, рис. 28,4-7; Abdullaev, 2008, p. 137-138], в дальнейшем, во II-I вв. до н.э., на территории от Центральной Азии до Нижнего Подонья получают распространение такие пряжки с рамкой прямоугольной формы, в которые вписаны или изображения лежащего верблюда, или сцены схватки животных [Скрипкин, 1990 , с. 98, тип 4, рис. 22,$30 ; 2000$, с. $17-26 ; 2006$, с. $13-14$, рис. 1,17-25; Королькова, 2006, с. 90-91, табл. 53,7-13,55; Brosseder, 2011, p. 384-388, fig. 35, lists 3a-b; Глебов, 2016, с. 69-79]. В первые века нашей эры пряжки такой конструкции с разными изображениями, вписанными в рамки, получают распространение как в Парфии, так и в Северном Причерноморье [Rostovtzeff, 1931, S. 46-55; Ghirshman, 1979, p. 170-176, pls. I-III; Post, 1995, S. 247-254;
Curtis, 2001, p. 299-327; Treister, 2003, p. 247257; Трейстер, 2015, с. 295-296] ${ }^{3}$. При этом ни у тех, ни у других пряжек в составе поясного набора наконечников ремней не фиксируется.

Золотая пряжка без инкрустаций такого же типа (прямоугольная со скругленными углами и с изображением ежа с задними лягушачьими лапками, с боковым крючком - выломанным из нее) происходит из ограбленного мужского погребения 5 кургана 70/1982 могильника у хут. Новый, изначально датированного II-I вв. до н.э., затем I в. до н.э. - I в. н.э. Пряжка принадлежала поясу, расшитому двумя рядами раковин каури [Власкин, 1989, с. 32-34, рис. 2; Дворниченко, Федоров-Давыдов, 1993, с. 174; Cat. Daoulas, 1995, p. 88-90, no. 112; Cat. Paris, 2001, p. 182, no. 201; Kat. Frankfurt, 2003, S. 119, Nr. 84; Brosseder, 2011, p. 384 , fig. 34 , p. 401, 424, list 9, no. 4]. Этот факт позволил У. Бросседер сопоставить пояс из Нового с находкой из Иволгинского могильника и рядовыми погребениями эпохи Западной Хань в Китае [Brosseder, 2011, p. 384]. Еще одна золотая пряжка со шпеньком на рамке, найденная в могильнике у хут. Новый, в погребении 4 кургана 46/1982, датированном по инвентарю II-I вв. до н.э., имеет подпрямоугольную форму, украшена рельефной зеркальной композицией из четырех головок ушастых грифонов с сильно изогнутыми клювами, а также круглыми глазами и ушами каплевидной форме, выполненными в виде кастов со вставками фиолетового стекла, попарно обращенных друг к другу, длинные шеи которых образуют узел в центре пряжки, где в округлом касте имеется стеклянная вставка [Власкин, 1989, с. 32-33, рис. 1; Cat. Paris, 2001, p. 183, no. 202].

Серебряная пряжка из датирующегося I - первой половиной II в. н.э. погребения 2 кургана 20/1982 у хут. Новый имеет прямоугольную форму со скругленными углами и украшена выполненной в высоком рельефе головой лося, изображенной сверху: ноздри, глаза, уши и лоб животного выделены гнездами для вставок разной формы со вставками из стекла и кости (рис. 7).

Голова лося в рельефе также является центральным элементом серебряной пряжки из погребения 1 кургана 1/1993 могильника 
Октябрьский I, датирующегося второй половиной I - началом II в. н.э. Глаза животного украшены округлыми выпуклыми вставками из темно-вишневого стекла. Гнезда в ушах в форме полуовалов заполнены вставками бирюзового фаянса. Однако конструктивно пряжка отличается тем, что прорезь для ремня сегментовидной формы имеется в ее основании треугольной формы, а загнутый шпенек в форме головы утки расположен на округлом кольце, зажатом в пасти лося [Мордвинцева, Мыськов, 1999, с. 179, рис. 1,10; Археологическое наследие, 2013, с. 112 (ил. вверху слева), № 259].

Вероятно, наиболее ранний комплект, включающий и пряжку со шпеньком, и наконечник ремня, выполненные в едином стиле и украшенные вставками бирюзы, - набор из Сибирской коллекции, происходящий из посылки князя М.П. Гагарина. Ажурная пряжка имеет подпрямоугольную форму с овальной передней частью и состоит из двух симметричных половин. Основу каждой половины составляют две пары голов стилизованных грифонов. Шеи той пары голов, которая ближе к центру, соединены в дугу; шеи другой пары как бы вырастают из голов первой пары. Глаза у птиц выложены бирюзой; она же, очевидно, украшала и шпенек с верхней поверхностью в форме каста каплевидной формы, который служил для застегивания этой пряжки. На противоположном конце пряжки помещена маленькая объемная фигурка ежа, вокруг которого извивается змея, пытающаяся укусить шею грифона, но еж, в свою очередь, схватил зубами змею. На ежах имеются маленькие полукруглые углубления, очевидно предназначенные для инкрустации. Наконечник пояса выполнен зеркально симметрично и отличается отсутствием шпенька на овальной рамке [Rudenko, 1962, S. 15, 50, Taf. II,4; Штейн, 1968, с. 269-272; Артамонов, 1973, c. 165 , рис. 217 ; Миняев, 1995 , с. 128-129, рис. 6,7; Minyaev, 2000, p. 294-295, fig. 5g; Мордвинцева, 2003, с. 84-85, № 34, рис. 13; Boardman, 2010, p. 72, nos. 341; Малашев, Дзуцев, 2016, с. 173, рис. 16,4]. Еще одну пару с зеркальным изображением образуют золотые пряжка со шпеньком и наконечник ремня с изображениями лежащих кабанов, со вставками из бирюзы и стекла, из коллекции Ш. Уайт и Л. Леви [Cat. New York, 1990, p. 63-64, no. 46; Bunker et al., 2002, p. 174-175, по. 162; Мордвинцева, 2003, с. 59, рис. 48,1-2]. Разнообразные поясные бляхи с зеркальными изображениями животных и грифонов представлены на парфянских скульптурах II-III вв. н.э. из Хатры [Curtis, 2001, p. 303-305, fig. 2 (тип с)].

Зеркальные образы представлены и на датированных I в. до н.э. - I в. н.э. ажурных пряжках с округлой рамкой с изображением орла с добычей в когтях (заяц, антилопа?) [Brosseder, 2011, p. 401, 424, list 9, nos. 10-11; Peterson, 2012, p. 23-24, fig. X. - Британский музей: Collon, 1995, fig. 160 (вверху); Curtis, 2001, p. 306, 327, pl. XIV,b; Rahbar et al., 2014, p. 301, 313, pl. 2,3). - Музей Метрополитен: Ghirshman, 1962, р. 100, fig. 112 (вверху); Cat. New York, 2000, p. 124-125, no. 95; p. 208], предположительно происходящих из гробницы, открытой в 1910-1911 гг. в районе Нихавенда в Иране [Herzfeld, 1928, p. 21-27; Rahbar et al., 2014, p. 301], и близких им по форме обувных пряжек с изображением вельможи в повозке с запряженным драконом из погребения IV некрополя Тилля-тепе (отлитых в характерной для поясных блях из Сибирской коллекции и китайских изделий технике lost wax - lost textile, возможно в Бактрии) [Sarianidi, 1985, S. 182-183, Taf. 124, S. 246, Nr. 4.1; Мордвинцева, 2003, с. 21, 83, № 11, рис. 5; Kat. Bonn, 2010, S. 195, 197, Nr. 106; Mordvintseva, 2010, p. 181, fig. 3,1, p. 185; Baumer, 2012, p. 292 (ill.); Boardman, 2012, p. 105 , fig. 3 ; Hickman, 2012, p. 84 , 85 , fig. 12 ; Patry Leidy, 2012, p. 112-113, figs. 2-3; Olbrycht, 2015, p. 354, fig. 14, p. 355]. Однако обе пары пряжек и из Тилля-тепе, и из Нихаванда имеют шпеньки, таким образом, функционально они не могут быть сопоставлены с находками из Косики.

Помимо представленного мотива ежа и змеи, пряжку из Сибирской коллекции с пряжкой из Косики сближает оформление шпенька каплевидным кастом со вставкой (бирюзы на пряжке из Сибирской коллекции, граната на пряжке из Косики). Подобным же каплевидным кастом, также со вставкой бирюзы, оформлен шпенек одной из двух золотых поясных пластин, найденных в Сидоровке [Матющенко, Татаурова, 1997 , с. 48 , рис. 27,2 ; Koryakova, 2006, p. 108, fig. 9,1; Brosseder, 2011, 
p. 375, 376, fig. 24,13]. Инкрустированные шпеньки со вставками каплевидной формы имелись также у золотых пряжек I в. до н.э. I в. н.э. из Дальверзин-тепе (вставка утрачена) [Pougatchenkova, 1978, p. 102, fig. 80; Curtis, 2001, p. 307; Мордвинцева, 2003, с. 56, рис. 43,7; Abdullaev, 2008, p. 138, fig. 3; Peterson, 2012, p. 24, fig. XI], из Нихавенда (вставка бирюзы на пряжке, хранящейся в Нью-Йорке), из Тилля-тепе (бирюза) и у серебряной пряжки из погребения 2 кургана 20/1982 могильника у хут. Новый (стекло темно-коричневого цвета) (рис. 7).

Округлая вставка на шпеньке, как и у наконечника пояса из Косики, имеется на пряжках из погребения кургана 12/1965 у с. Никольского (вставка из стекла) [Засецкая, 1979, с. 111 , рис. 22 ; Мордвинцева, 2003, с. 42,88 , № 58, рис. 22; Мордвинцева, 2007, с. 214, 223, 227, 238; Мордвинцева, Трейстер, 2007, т. 2, c. 49, № A146.2, рис. 33, табл. 32; Mordvintseva, 2010, p. 195-196, no. 3, fig. 11,1; Brosseder, 2011, p. $398-401$, fig. 47,2 , p. 421 , list 5 , no. 2 ; Засецкая, 2012 a, с. 356 , № 2 , с. 365 , 368-369, 372, рис. 1,3-4; Засецкая, 20126, с. 71, рис. 8 ; Shu Takahama, 2012, p. 28, no. D-1, fig. 4,1; Засецкая, 2013 , с. 141 , рис. 2,4, с. 143-144; Mordvintseva, 2016, p. 388, 397, 416, pl. VI,3] (рис. 8) и Порогов (бирюза) [Симоненко, Лобай, 1991, с. 14-18, № 7a-b, рис. 8-9, табл. 1112; Kat. Schleswig, 1991, S. 328, 405, Nr. 155a; Cat. Milan, 1995, p. 124, 198, no. 68; Мордвинцева, 2003, с. 40, 43, 51, 73, 78, 95, № 107, рис. 40; Мордвинцева, 2007, с. 214, 225, 228, 238; Мордвинцева, Трейстер, 2007, т. 2, с. 73, № А234.7, табл. 38, рис. 50; Mordvintseva, 2010, p. 197, no. 8, fig. 11,9; Brosseder, 2011, p. 401, 403, fig. 50,29-30, p. 424, list 9, no. 7; Засецкая, 2012б, 66-67, № 5, рис. 4,1].

Отличаются пряжка и наконечник ремня из Косики от приведенных выше аналогий и способом крепления к ремням. Так, на обороте пряжки и наконечника ремня из Сибирской коллекции имеются по две широкие петли для продевания ремня. Остатки серебряных петель отмечаются и на пластинах из коллекции Ш. Уайт и Л. Леви - сколько их было и как они располагались, однако, из описания неясно. Петли, но из бронзы, имелись на обороте пластин из Сидоровки, из которых сохранилась лишь одна. Судя по прорисовке, сохра- нившаяся небольшая петля находится в углу пластины, а ось отверстия расположена перпендикулярно оси пластины. На оборотных сторонах пряжки и наконечника ремня из Косики в углах имеются небольшие округлые пластинчатые петли (на каждой их изначально было - по четыре, одна петля утрачена), которые могли служить либо для продевания шнуров вдоль нижнего и верхнего краев пластин, либо, что значительно менее вероятно, нашивания на основу. Ближайшей параллелью является конструкция петель на пряжках из погребения IV в Тилля-тепе - это также четыре небольшие петли округлой формы, припаянные на равном расстоянии друг от друга. В какой-то степени близкую систему крепления имела поясная пряжка прямоугольной формы с рельефным изображением сирены из Барановки, к оборотной стороне бронзовой основы которой были приклепаны шесть (сохранилось пять) бронзовых петель, позволяющих протянуть два шнура вдоль верхнего и нижнего края пряжки (рис. 9, 10), либо, что менее вероятно, как и в случае с пряжкой и наконечником пояса из Косики, пришить ее к основе. На пряжке из кургана 20 у хут. Новый к оборотной стороне по центральной продольной оси припаяны две петли, с отверстиями не в продольном направлении, как у пряжек из Косики и Барановки, а в поперечном. У золотой пряжки из кургана 70/1982 могильника у хут. Новый на оборотной стороне пряжки в районе брюха животного имеется сломанная в древности петля, а для крепления к ремню использовались также два небольших отверстия, пробитые в углах пряжки на стороне. Шпенек, вставлявшийся в отверстие на рамке, был вырван - сохранилось лишь квадратное отверстие, в которое он вставлялся. У пряжки из кургана 46/1982 могильника у хут. Новый также имеются два отверстия на рамке в задней части пряжки, а в передней - сохранился шпенек. Подобную же конструкцию с двумя отверстиями на пряжке сзади имеет костяная пряжка с рельефным изображением совы из Косики: в эти два отверстия вставлены золотые заклепки, а в отверстие спереди на рамке - золотой шпенек (рис. 11) [Дворниченко, ФедоровДавыдов, 1993, с. 175 , рис. 20,2, с. 176 (названа поясной накладкой, но функционально, учитывая наличие шпенька спереди на рамке и 
прорези для ремня, безусловно, является пряжкой. - M. T.); Cat. Rome, 2005, p. 119, no. 63; Mordvintseva, 2016, p. 388, 397, 416, pl. VI,7].

\section{4. Какие еще детали могли относиться к поясному набору?}

То обстоятельство, что находки из Косики происходят из разрушенного погребения, далеко не весь инвентарь которого до нас дошел, затрудняет ответ на этот вопрос. Тем не менее обращают на себя внимание два узких золотых наконечника ремня.

Один из них - гладкий, второй - украшен с двух сторон в технике клуазоне. На одной стороне - два продольных ряда из каплевидных проволочных кастов со вставками из эмали голубого цвета, образующих цепочку, с другой - два продольных фриза из треугольных кастов из напаянной рубчатой проволоки со вставками из эмали синего цвета (рис. 12) [Дворниченко, Федоров-Давыдов, 1993 , с. $158-159$, рис. 11,1 ; Fedorov-Davydov, 2001 , p. 118 , pls. $34-35$, p. 148 , no. 13 ; Treister, 2004 b, p. 212 , no. 20a; Cat. Rome, 2005, p. 118, nos. 60-61; Мордвинцева, Трейстер, 2007, т. 2 , c. 42, № A114.10, табл. 78].

Имели ли эти наконечники ремней, находящие параллели в погребениях из Первомайского, Порогов, Цветны и Усть-Альминского могильника (см. подробно: [Treister, 2004b, p. 194, fig. 3,14-20, p. 199-202; Трейстер, 20076 , с. 290-291]) и в погребении IV в Тилля-тепе [Sarianidi, 1985, S. 155, Taf. 98, S. 247, Nr. 4.4, S. 251, Nr. 4.34; Curtis, 2001, p. 307; Kat. Bonn, 2010, S. 199, Nr. 109, S. 209, Nr. 124; Brosseder, 2011, p. 404, fig. 51,7-9], отношение именно к ремню с пластинами, украшенными изображениями ежей - вопрос, на который трудно однозначно ответить, учитывая то, что ни один из двух косикских наконечников по своему оформлению никак не связан с декором блях с ежами. В поясном наборе из погребения 3 кургана 14/1984 могильника Первомайский VII и бляхи ремня, и близкий по форме наконечник пояса оформлены в одной технике и с использованием одних и тех же декоративных фризов [Симоненко, Лобай, 1991 , с. 50-52, рис. 27,3,6; Мамонтов, 2000, 17-19, рис. 16,4-5,9; Treister, 2004b, p. 194, fig. 3,12-14, p. 213-214, no. 26]. О том, что это не всегда могло иметь место, свидетельствует тот факт, что в погребении 5 кургана 70/1982 могильника у хут. Новый, из которого происходит золотая пряжка с изображением ежа с лягушачьими лапками, был найден узкий наконечник пояса такой же формы, как в Косике, но из железа [Ильюков, Власкин, 1992 , с. 81,83 , рис. 20,9$]$. Также и в погребении в Порогах наконечники пояса с декором в технике клуазоне из прямоугольных (или почти ромбовидных) кастов (один из них с тамгообразным знаком на оборотной стороне) [Kat. Schleswig, 1991, S. 404 (Farbtaf.); Симоненко, Лобай, 1991, с. 20, рис. 11,3-4, с. 22 , № 9, g. $D$, с. $50-52$, рис. $27,1-2$, табл. 16,1-2; Cat. Milan, 1995, p. 129 (ill.), p. 198, no. 72; Simonenko, 2001, S. 230, 232, Abb. 23,1; Treister, 2004b, p. 194, fig. 3,18-20, p. 213, no. 21; Мордвинцева, Трейстер, 2007, т. 2, с. 73, № А234.4, табл. 78, рис. 17; Brosseder, 2011, p. 400, 403, fig. 50,25-26; Симоненко, 2015, c. 71-72, цв. вкл. 1,3 , с. 73 , рис. 20,3$]$ никаким образом не соответствуют по стилю поясным бляхам и накладкам, ни портупейного ремня, к которому они предположительно относятся [Brosseder, 2011, p. 400, 403, fig. 50,2128; Симоненко, 2015, с. 71-72, цв. вкл. 1,3, c. 73, рис. 20,1-7], ни парадного пояса. Интересно, что и в тайнике кургана 3/1988 у с. Хапры золотые поясные пластины были также найдены вместе с аналогичным наконечником пояса с декором в технике клуазоне из прямоугольных кастов [Гордин, 1989, л. 24, рис. 101].

Учитывая уровень исполнения рассматриваемых блях поясной гарнитуры из Косики, их уникальную конструкцию с потайными отделениями, трудно представить себе, что относящиеся к этой же поясной гарнитуре узкие наконечники ремней могли настолько не соответствовать по своему декору этим бляхам, разве что в процессе использования ремня изначальные узкие наконечники, свисавшие с пояса, если они и были, в связи с утратой были заменены. Не надо забывать, что в рассматриваемом погребении в Косике была найдена и упомянутая выше костяная пряжка с изображением совы и золотыми штифтами для крепления к поясу и золотым шпеньком (рис. 11). 


\section{5. Сюжет. Еж и змеи}

Образ ежа в древнем искусстве особой популярностью не пользовался [Werness, 2003, p. 210-211], если исключить египетские скарабеи и фаянсовые алабастры архаического времени.

Золотая пронизь в виде фигурки ежа на постаменте предположительно эллинистического времени в собрании Кливлендского музея изображает фигурку животного с телом, полностью покрытым шариками зерни [Gift..., 1985]. Другая золотая пронизь в форме ежа, также полностью покрытого зернью, но не с продольным, а с поперечным отверстием, имеется в Сибирской коллекции [Rudenko, 1962, S. 60, Taf. XXI,33; Штейн, 1968, с. 271; Артамонов, 1973, с. 195, рис. 252]. Наконец, еще одна золотая пронизь была найдена при раскопках храма в центральной части городища Еркурган [Древнейшие государства, 1985, с. 291, табл. CXXXVII,9; Рахманова, 1990, с. 83; Яценко, 2000, с. 174; Сулейманов, 2000, с. 127-130; Мордвинцева, 2003, с. 56, рис. 43,6; Абдуллаев, 2011, с. 317; Малашев, Дзуцев, 2016, с. 173, рис. 16,3], слои которого датируются не ранее IV в. н.э. Полая трубочка для шнура припаяна к основанию фигурки. Отличительной особенностью фигурки является использование многочисленных высоких пластинчатых кастов различной формы (круглых и в форме криволинейных треугольников). В семи из 49 клуазонов сохранились вставки бирюзы. Вся спинка ежа представляет собой большое округлое гнездо со вставкой выпуклой перламутровой раковины белого цвета ${ }^{4}$. Вероятно, их прототипы следует искать на востоке. Действительно, в Китае ежи почитались как tasheng, или Великий Дух [Werness, 2003 , p. 211]. В этой связи укажем на находку десяти золотых нашивных бляшек в форме ежей в погребении в Алушайдене, Внутренняя Монголия, датированном III в. до н.э. [Tian, Guo, 1980, p. 335, fig. 3, 12, pl. 11, 5; Psarras, 1995, p. 119, 122, fig. 11; Bunker, 1997, p. 51, fig. A59, p. 237; Di Cosmo, 1999, p. 955; Cat. Paris, 2000, p. 125, no. 113; Boardman, 2010, p. 69 , no. 311, pl. 42; Hsu, 2010, p. 13-14, 24 , fig. 16,6]. Аналогичные бляшки из серебра были найдены в погребении в Шихуигоу во Внутренней Монголии [Bunker, 1997, p. 237].
Впрочем, известно, что еж почитался и номадами Центральной Азии и Ирана, отвечая за дары природы и огонь [Werness, 2003 , p. 211]. От внимания исследователей ускользнула находка пяти сбруйных (?) серебряных бляшек в форме фигурок ежей, с пластинчатыми петлями на обороте [Спицын, 1909, с. 29, 48, рис. 73; Малашев, Дзуцев, 2016, с. 173, рис. 16,5] вместе с фаларами парфянской работы (?) и кольцами при распашке кургана в окрестностях Новоузенска в 1884 г. Иглы переданы выбитыми с оборотной стороны выступами треугольной и ромбовидной формы. Учитывая наиболее вероятную датировку фаларов в пределах II - начала I в. до н.э., есть все основания предполагать, что новоузенские бляшки являются наиболее ранними изображениями ежей в древностях кочевников Азиатской Сарматии.

На этом фоне обращает на себя внимание то, что мотив ежа в схватке со змеей получает распространение именно на поясных пластинах (пряжках и наконечниках поясов), выполненных из золота и, по крайней мере, в одном случае, исполненных в полихромном стиле. Пряжка и наконечник пояса из Сибирской коллекции [Rudenko, 1962, S. 15, 50, Taf. II,4; Штейн, 1968, с. 269-272; Артамонов, 1973 , с. 165 , рис. 217 ; Миняев, 1995 , с. $128-$ 129, pис. 6,7; Minyaev, 2000, p. 294-295, fig. 5g; Boardman, 2010, p. 72, nos. 341] относятся к тому же типу, что и рассматриваемые детали поясного набора из Косики.

Золотая пряжка без инкрустаций такого же типа (с боковым крючком - выломанным из нее) происходит из ограбленного мужского погребения 5 кургана 70/1982 могильника у хут. Новый, изначально датированного II-I вв. до н.э., затем I в. до н.э. - I в. н.э. Пряжка принадлежала поясу, расшитому двумя рядами раковин каури [Власкин, 1989, с. 32-35, рис. 2; Дворниченко, Федоров-Давыдов, 1993, c. 174; Cat. Daoulas, 1995, p. 88-90, no. 112; Cat. Paris, 2001, p. 182, no. 201; Kat. Frankfurt, 2003, S. 119, Nr. 84; Brosseder, 2011, p. 384, fig. 34, p. 401, 424, list 9, no. 4]. Этот факт позволил У. Бросседер сопоставить пояс из Нового с находкой из Иволгинского могильника и рядовыми погребениями эпохи Западной Хань в Китае [Brosseder, 2011, p. 384]. 
Всю поверхность пряжки из кургана 70/1982 могильника у хут. Новый занимает рельефное изображение, которое М.В. Власкин [1989, c. 33] определяет как «фантастическое животное» с туловищем ушастого ежа и задними лягушачьими лапками, с чем нельзя не согласиться. Изогнутые отростки рядом с передними лапками определяются как стилизованные изображения змей, а завитки по сторонам от отверстия для ремня - как стилизованные изображения головок хищных птиц. Таким образом, есть все основания предполагать, что пряжка из кургана 70/1982 могильника у хут. Новый в определенной степени имитировала композицию пряжки из Косики, будучи выполненной в значительно более примитивной манере, при этом еж трансформировался в существо с задними лягушачьими лапками.

Уже в первой публикации находок из Косики указывалась их связь с рассмотренными выше некоторыми из предметов, такими как пряжка и наконечник пояса из Сибирской коллекции, пряжка из могильника у хут. Новый, амулет из Еркургана и ордосские бронзы, при этом в качестве ближайшей параллели рассматривалось украшение из Еркургана, а пряжке и наконечнику ремня из Косики приписывалось вероятное южносибирское или среднеазиатское происхождение [Дворниченко, ФедоровДавыдов, 1993, с. 173-174]. В.И. Мордвинцева отмечала, сравнивая пряжки из Сибирской коллекции из Косики, что «отличие обеих композиций состоит в том, что на пряжках из Косики основным персонажем является еж, что подчеркивается его размерами и вниманием к декору, а на сибирских застежках сцене борьбы ежа и змеи уделяется мало внимания, зато второстепенный по отношению к основному сюжету мотив занимает основное декоративное пространство. Если обе композиции восходят к одному прототипу, то пряжки из Косики стоят к нему ближе, чем сибирские, и могут быть датированы раньше» [Мордвинцева, 2007, с. 225]. Указывая в качестве параллелей на пряжки из Сибирской коллекции и пряжки хунну, а также на амулет из Еркургана, В.И. Мордвинцева приходит к выводу, что «перечисленных параллелей недостаточно, чтобы делать какие-либо серьезные выводы о происхождении косикинских пряжек» [Mор- двинцева, 2003, с. 44; Мордвинцева, 2007, с. 229]. У. Бросседер ставит пряжку из Косики в один ряд с пряжками из погребения 4 в Тилля-тепе, Порогов, Нихавенда, то есть в группу пряжек, которые не могут быть отнесены к какому-то определенному типу «List 9. Ostentatious belts or belt plaques which cannot be attributed to a specific type» [Brosseder 2011, p. 401,424 , list 9 , no. 2 ].

\section{6. Атрибуция}

В.Ф. Штейн [1968, с. 269-272], проанализировав сюжет изображений на пряжке и наконечнике пояса из Сибирской коллекции (еж, убивающий змею), обратил внимание на то, что этот сюжет, не характерный для искусства Сибири, был довольно распространен в ордосских бронзах, и отнес пряжку из Сибирской коллекции к кругу памятников сюнну ${ }^{5}$. Есть основания полагать, что рассматриваемые пряжка и наконечник ремня из Сибирской коллекции послужили прототипами для некоторых бронзовых пряжек сюнну [Миняев, 1995, с. $128-129$, рис. 6,8; Minyaev, 2000, p. 294-295, fig. 5h].

В том, что композиция и сюжет пряжки из Косики определенным образом связаны с пряжкой и наконечником пояса из Сибирской коллекции, сомнений нет. Разница заключается не только в тех моментах, которые уже были отмечены исследователями, а еще и в том, что на пряжках из Косики грифоны присутствуют в рудиментарной форме - головок с глазами и ушами, обозначенными вставками, а еж змей не хватает - они образуют за спиной ежа «гераклов узел», своими завязанными хвостами обвивают по сторонам фигурку ежа, при этом передние части змей свернутыми петлями, а их головками лежат поверх лап ежа (еж не хватает змей и не душит их - схватка со змеями уже явно завершена, ср.: [Власкин, 1989, с. 34; Мордвинцева, 2007, c. 225]). Таким образом, мне трудно представить, в отличие от В.И. Мордвинцевой, что пряжка и наконечник ремня из Косики были ближе прототипу, чем рассмотренные предметы из Сибирской коллекции. Скорее всего, все обстояло наоборот.

Несмотря на то что сюжет и композиция декора пряжек из Косики восходит веро- 
ятнее всего к ордосским бронзам, возможно опосредованно (через прототипы, подобные предметам из Сибирской коллекции, место изготовления которых неизвестно) в трактовке изображений змей прослеживается иконография эллинистического искусства. Именно так (с петлей туловища перед головкой) изображались змеи, в частности в ювелирном искусстве, будучи распространенным мотивом оформления колец и особенно браслетов. Интересно, что такие браслеты, получившие широчайшее распространение в эпоху эллинизма, особенно во второй половине III - первой половине II в. до н.э. [Pfrommer, 1990, S. 126138, Abb. 18, S. 348-353, Taf. 22], известны и по находке на территории Афганистана (с весовой надписью, в которой обозначен вес, скоpeе всего, в птолемеевских драхмах) [Bernard, Bopearachchi, 2002, p. 237-240, figs. 1-3, p. 245-247, fig. 8]. Эллинистическим мотивом, безусловно, является и «гераклов узел» [Pfrommer, 1990, S. 4-80], которым завязаны змеи и который в сильно схематизированном виде представлен на пряжке из кургана 46 могильника у хут. Новый - здесь узел образован переплетенными шеями грифонов. Интересно, что в центральной части более поздних, датирующихся серединой - второй половиной I в. н.э. золотых ажурных пряжек предположительно парфянской и боспорской работы в центральной части также имеется «гераклов узел» ${ }^{6}$, известны также нашивные бляшки в форме «узла Геракла», в частности из тайника кургана у пос. Дачи [Беспалый, 1992, с. 179, рис. 3,9 , с. 180,189$]$.

И на пряжке из Саксанохура, на которой представлен всадник-кочевник, охотящийся на кабана, также прослеживаются определенные влияния эллинистического искусства - в оформлении края фризом ионийского киматия ${ }^{7}$, пусть и переданного в несколько варваризованной манере. Подобный же декор оформляет по краю и пряжки из Нихавенда, более того, их петли с прорезями для ремней оформлены полулистами аканфа. В еще большей степени влияние эллинистической составляющей проявилось в золотой пряжке неизвестного происхождения с антикварного рынка в Узбекистане со сценой схватки героя (Геракла?) с кентавром - типологически пряжка также относится к рассматриваемому типу пря- жек со шпеньком (в данном случае он округлый в плане и украшен вставкой из темно-синего камня) [Abdullaev, 2008, p. 135-137, fig. 1; Boardman, 2015, p. 108-109, fig. 58].

Обращают на себя внимание и использование принципиально других материалов вставок. Если рассмотренные пряжки из Сибирской коллекции, Дальверзин-тепе, Тиллятепе, Нихавенда инкрустированы исключительно вставками из бирюзы, а пряжки из Сидоровки - бирюзой, кораллом и янтарем, амулет из Еркургана - вставками из бирюзы и раковины, то в пряжке и наконечнике пояса из Косики использованы гранаты и стекло. Интересно, что из подобных же материалов, стекла и гранатов, выполнены вставки округлой (стекло голубого цвета) и каплевидной формы на бронзовых позолоченных фаларах из бывшей коллекции Н. Шиммеля, в настоящее время хранящихся в Музее Метрополитен, предположительно происходящих из Западной Азии и являющихся парфянской работой последних веков до нашей эры или I-II вв. н.э. [The Metropolitan Museum, 1992, p. 56, nos. 26-27; Treister, Yatsenko, 1998, p. 71-72, 105, figs. 17-18; Cat. New York, 2000, p. 126127, fig. 96]. Предположение о происхождении этих фаларов подкрепляется находкой пары очень близких им по декору с композицией также из трех вихреобразно закрученных голов грифонов на шеях, сгруппированных вокруг центрального каста треугольной формы в отличие от фаларов из Музея Метрополитен эти фалары, вероятно, обнаруженные на территории Иранского Азербайджана, имеют по краю бордюр не из круглых кастов, а в форме ов, а сами головки грифонов несколько отличаются по деталям исполнения [Zimmermann, 1991, p. 96, fig. 28; Schiltz, 1994, S. 71, Abb. 46, S. 72; Treister, Yatsenko, 1998, p. 59-60; Le profane et le divin, 2008, p. 403 (ill.), 508 (с датировкой V-IV вв. до н.э.)] ${ }^{8}$. И наконец, третьей парой фаларов, обнаруживающих близость рассмотренным выше, - является находка, сделанная в том же погребении в Косике, что и публикуемые пряжка и наконечник ремня. Нам точно неизвестен материал вставок в поле серебряной пластины с рельефным изображением льва, нападающего на оленя (сюжет, находящий параллели на предположительно происходящих с территории 
Северо-Западного Ирана фаларах, поступивших в Музей Гетти [Pfrommer, 1993, p. 5-13, 155-160, nos. 30-33]), предположительно происходящей из Дайламана в Иране и хранившейся в начале 1960-х гг. в коллекции Д. Заликовиц в Нью-Йорке, но, судя по черно-белой фотографии, и округлые, и каплевидная вставки были темные [Cat. Paris, 1961, p. 124, no. 733A, pl. LXXVII; Pfrommer, 1993, p. 72, note 43].

Касты для вставок на пряжке и наконечнике ремня из Косики, однако, обнаруживают определенную близость кастам на амулете из Еркургана. В первую очередь это касается высоких кастов округлой формы, покрывающих поверхность фигурки ежа (но не спинки) довольно плотно, пусть и не сплошь, как и на спинках ежей из Косики. Другой относительно близкий пример плотного использования высоких кастов, в данном случае со вставками бирюзы - по краю - и граната - в центре представлен на верхних элементах фаларов с крупными агатовыми вставками, фигурками львов и вставками гемм, вероятнее всего, боспорской работы I в. н.э., найденных в тайнике кургана у пос. Дачи под Азовом [Cat. Tokyo, 1991, p. 105, no. 112; Беспалый, 1992, c. 182-183, № 6, рис. 8-9; Kat. Zürich, 1993, S. 261 ; Cat. Daoulas, 1995 , p. $70-71$, nos. 100 101; Treister, Yatsenko, 1998, p. 57, 104, fig. 13; Cat. Paris, 2001, p. 209-210, no. 235; Mordvinceva, 2001, S. 86-87, Nr. 112, Taf. 56; Мордвинцева, 2003, с. 38, 52, 80, 90, № 78, рис. 33 ; Treister, $2004 \mathrm{a}$, p. 163 , no. 7 , fig. 7 ; Treister, 2004 b, p. 193 , fig. 2,4 , p. 210 , no. 9 b; Мордвинцева, 2007, с. 223, 231, 237, 239; Трейстер, 2007в, с. 303; Мордвинцева, Трейстер, 2007 , т. 2 , с. 28 , № А67.2, табл. $26,78,79$, рис. 44; Кат. Ст. Петербург, 2008, с. 100-103, № 22; Kat. Leoben, 2009, S. 222-225, Nr. 83].

В то же время конструкция некоторых кастов, прежде всего, каплевидных - на съемных элементах и круглого и каплевидного на шпеньках, отличается тем, что камни вставлены в углубления кастов в своих собственных оправах, край которых загнут сверху внутрь для лучшей фиксации камня. Этот признак абсолютно не характерен для кастов украшений из Сибирской коллекции и Тилля-тепе [Мордвинцева, 2007, с. 233-237; Mordvintseva, 2010, p. 184, fig. 6, p. 187; Hickman, 2012, p. 80
82], с одной стороны, и, наоборот, был весьма распространен в Восточном Средиземноморье в эпоху позднего эллинизма и в первые века нашей эры. Хотя уровень и качество публикаций лишь в редких случаях позволяет судить об этом, тем не менее, среди находок из кораблекрушения у о. Антикиферы есть отдельный золотой каст со вставкой ромбовидной формы - издатели, справедливо отмечая отсутствие каких-либо следов фиксации, приходят к выводу о том, что каст со вставкой сам должен вставляться в другой каст на ювелирном украшении [Stassinopoullou, 2012, p. 147, no. 116]. О конструкции таких двойных кастов дают представления серьги и с подвесками из того же комплекса, у одной из которых внутренние касты со вставками утрачены, а у других сохранились [Stassinopoullou, 2012, p. 148-149, nos. 118-119] ${ }^{9}$. Находки различных категорий, в том числе амфоры с клеймами (Родос, Эфес, Кос) [Kourkoumelis, 2012, p. 211] и монеты [Tselekas, 2012, p. 218], датируют кораблекрушение временем не позднее середины І в. до н.э., с большой долей вероятности (по монетам): 70-60-ми гг. до н.э. Известны и другие примеры таких двойных кастов в ювелирных изделиях из Восточного Средиземноморья, Греции, Малой Азии и Закавказья позднеэллинистического времени [Трейстер, 2007 a, c. 277 , тип 10], в том числе из клада «в квартале ювелиров», найденного на Делосе в 1964 г. и датированного 122 или 88 г. до н.э. [Hackens, Lévy, 1965, p. 533-534].

Особого внимания заслуживает наличие потайных отделений со съемными крышками пряжки и наконечника ремня. О том, что перстни с секретными отделениями для яда были в употреблении в античности, имеются сообщения в письменных источниках, в частности о том, что такие перстни помогли покончить с жизнью Демосфену (Plin. XXXIII, 25) и Ганнибалу (Cornelius Nepos, Hannibal 12.5; Juvenal, Satires X.164) [Marshall 1907, XXIII]. Интересно, что и пряжки с секретными отделениями у сарматов не исчерпываются находкой в Косике. У более поздней пряжки, вероятно боспорской работы, найденной под Воронежом (Титчиха) и, скорее всего, относящейся к инвентарю разрушенного погребения I в. н.э., к откидному язычку была припаяна прямоугольная коробочка со съемной крышкой, украшен- 
М.Ю. Трейстер. Драгоценный поясной набор из элитного погребения кочевника у с. Косика

ной четырьмя листами плюща, черенки которых переплетаются в центре, образуя «гераклов узел» [Смирнов, 1940, с. 364, № 3, рис. 3].

\section{Выводы}

Конструкция пряжек и представленный на ней сюжет дают основание предположить, что элементы этого поясного гарнитура создавались специально для кочевника, выходца из Восточной Евразии. Изначальная концепция, которая, вероятно, была представлена на пряжке и наконечнике пояса из Сибирской коллекции и в которой еж был лишь одним из героев сюжета, обезвреживая змей, кусающих грифонов, была изменена, и теперь представляла ежа триумфатором, с задушенными им змеями, завязанными «узлом Геракла» за его спиной и редуцированными изображениями грифонов, сокращенных до головок. В композиции были введены элементы декора, характерные для эллинистического ювелирного дела - «узел Геракла», и использован типичный для Восточного Средиземноморья II-I вв. до н.э. прием двойных кастов, при котором в углубление для вставки помещался камень со своим кастом, края которого были загнуты внутрь. Вместо характерных для пряжек китайского, центрально-азиатского и парфянского происхождения вставок бирюзы были использованы вставки граната и стекла, которые, впрочем, применялись для декора фаларов предположительно парфянского происхождения. С учетом всех этих наблюдений логично предположить изготовление элементов поясной гарнитуры из Косики специально для заказчика-кочевника в высокоспециализированной мастерской торевта. С наибольшей вероятностью это могло произойти во второй половине II - I в. до н.э. в Иране или в Малой Азии. Пояс, к которому относились публикуемые пряжки, учитывая их уникальное конструктивное и художественное исполнение, а также, безусловно, высокую материальную ценность (и пряжка, и наконечник весят около 53 г высокопробного золота каждая), был статусным предметом и, возможно, даже инсигнией царской власти - не случайно на позднепарфянских скульптурах из Хатры пояса с подобными бляхами носят либо цари, либо представители высшей знати [Curtis, 2001, p. 308-310]. 


\section{ИЛЛЮСТРАЦИИ}
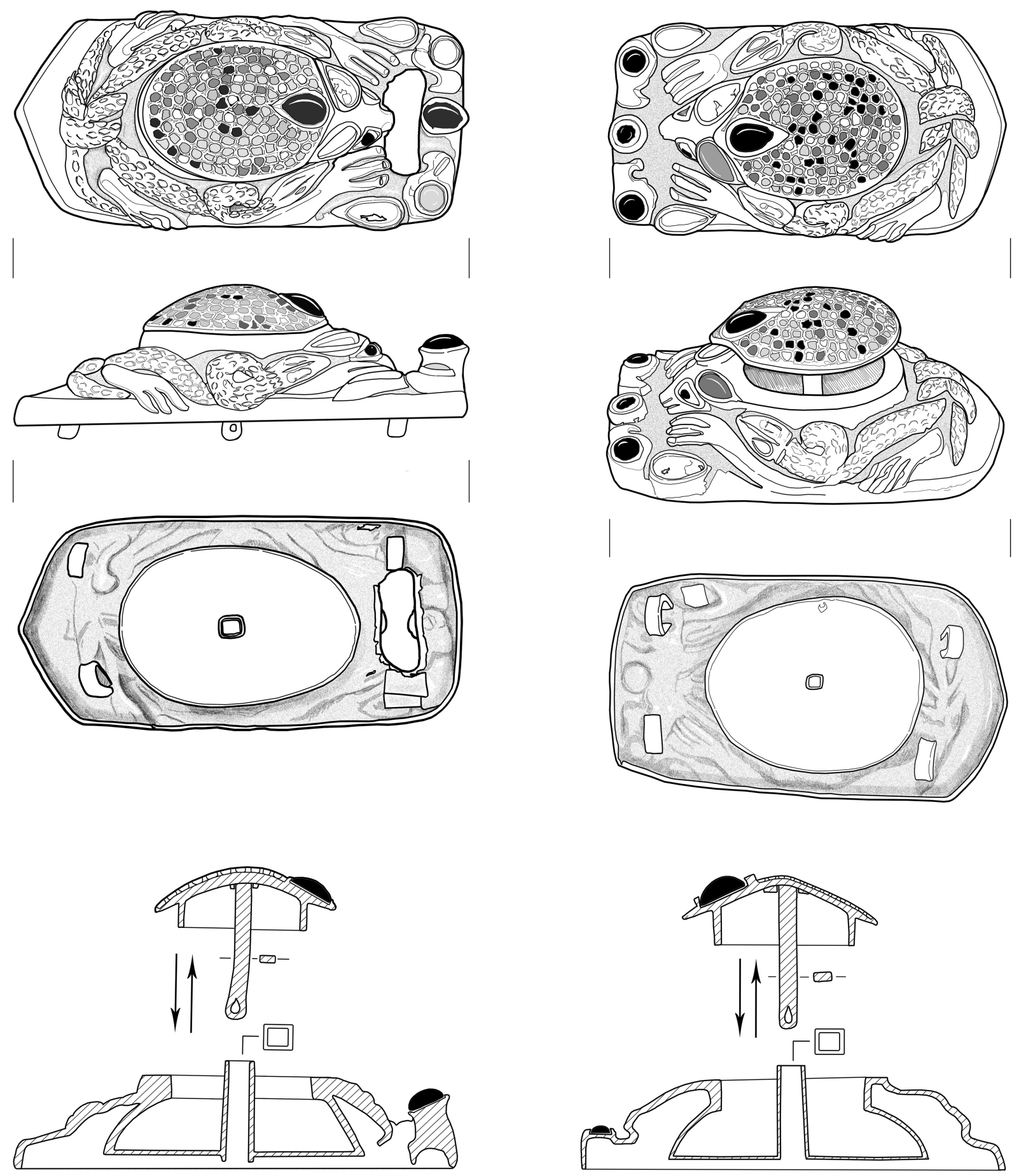

1

2

Рис. 1. Пряжка и наконечник ремня из погребения 1/1984 у с. Косика. Рисунки Н.Е. Беспалой

Fig. 1. The buckle and the belt tip from burial no. 1/1984 near the village of Kosika. Drawings by N.E. Bespalaya 
М.Ю. Трейстер. Драгоценный поясной набор из элитного погребения кочевника у с. Косика
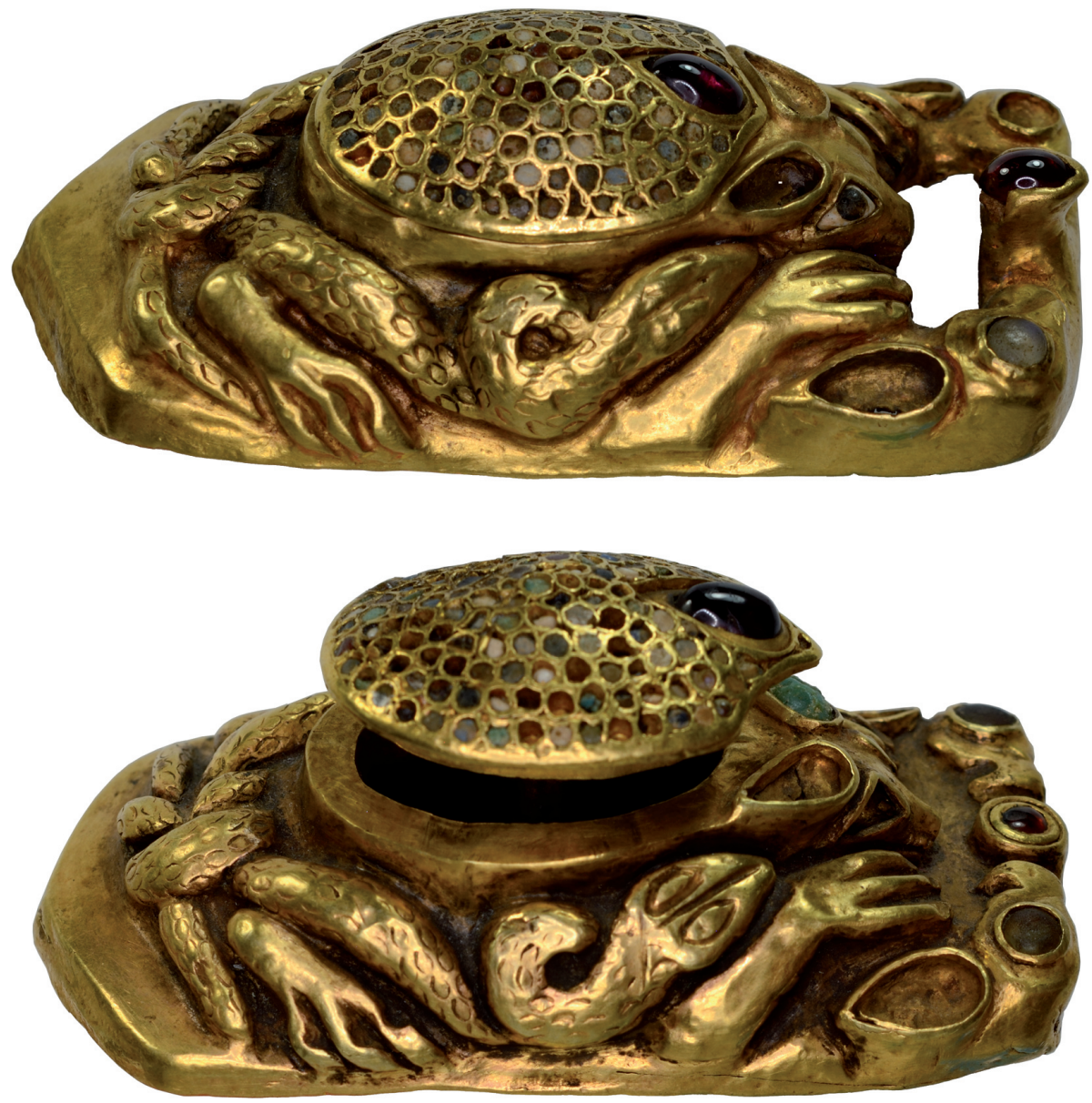

2

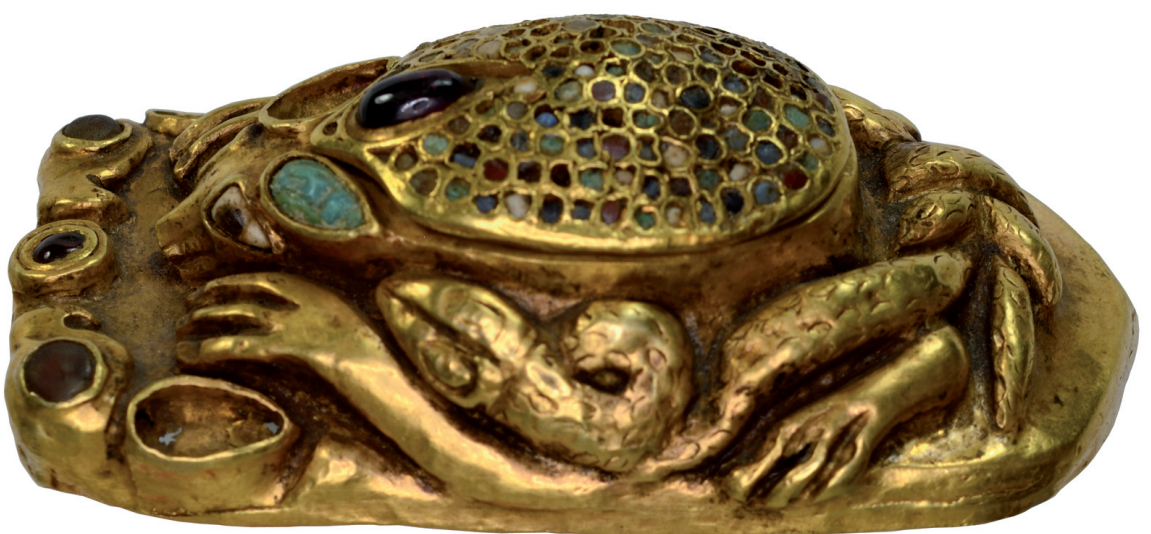

Рис. 2. Пряжка и наконечник ремня из погребения 1/1984 у с. Косика.

Астрахань, Государственный объединенный историко-архитектурный музей-заповедник, инв. № 35528-35529. Фотографии М.Ю. Трейстера:

1 - пряжка; 2, 3 - наконечник пояса

Fig. 2. The buckle and the belt tip from burial no. 1/1984 near the village of Kosika.

Astrakhan, State United Historical-Architectural Museum-Reserve, inventory nos. 35528-35529.

Photographs by M. Treister:

1 - buckle; 2, 3 - belt tip 
M.Yu. Treister. A Precious Belt Set from the Nomadic Elite Burial near the Village of Kosika

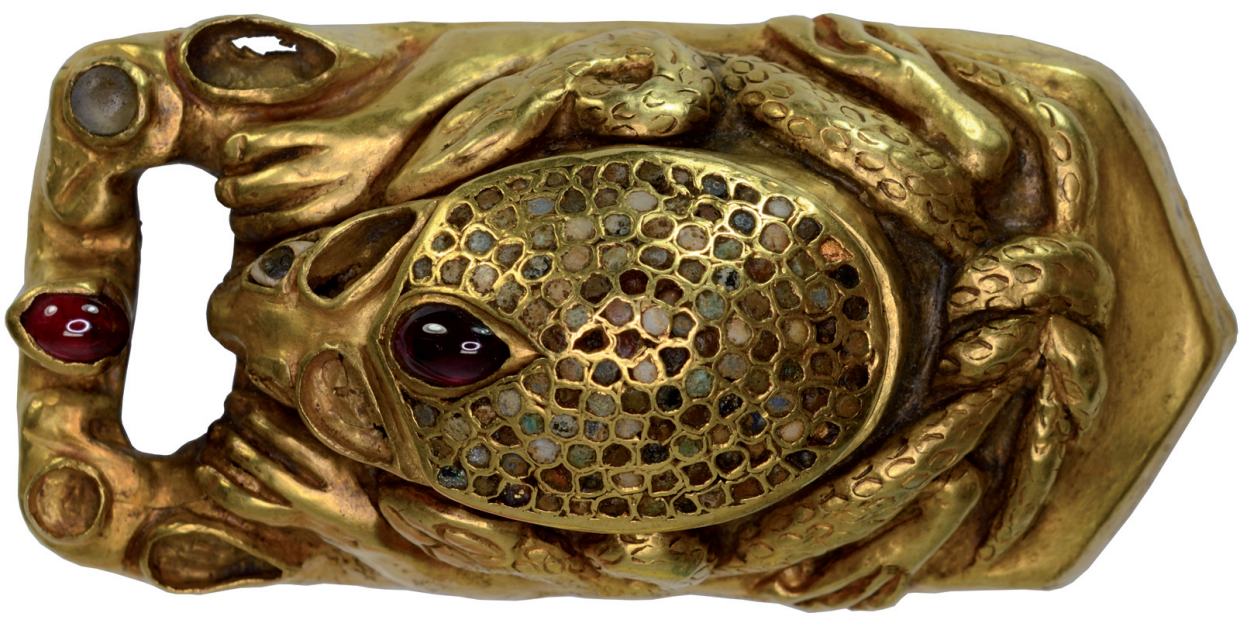

2
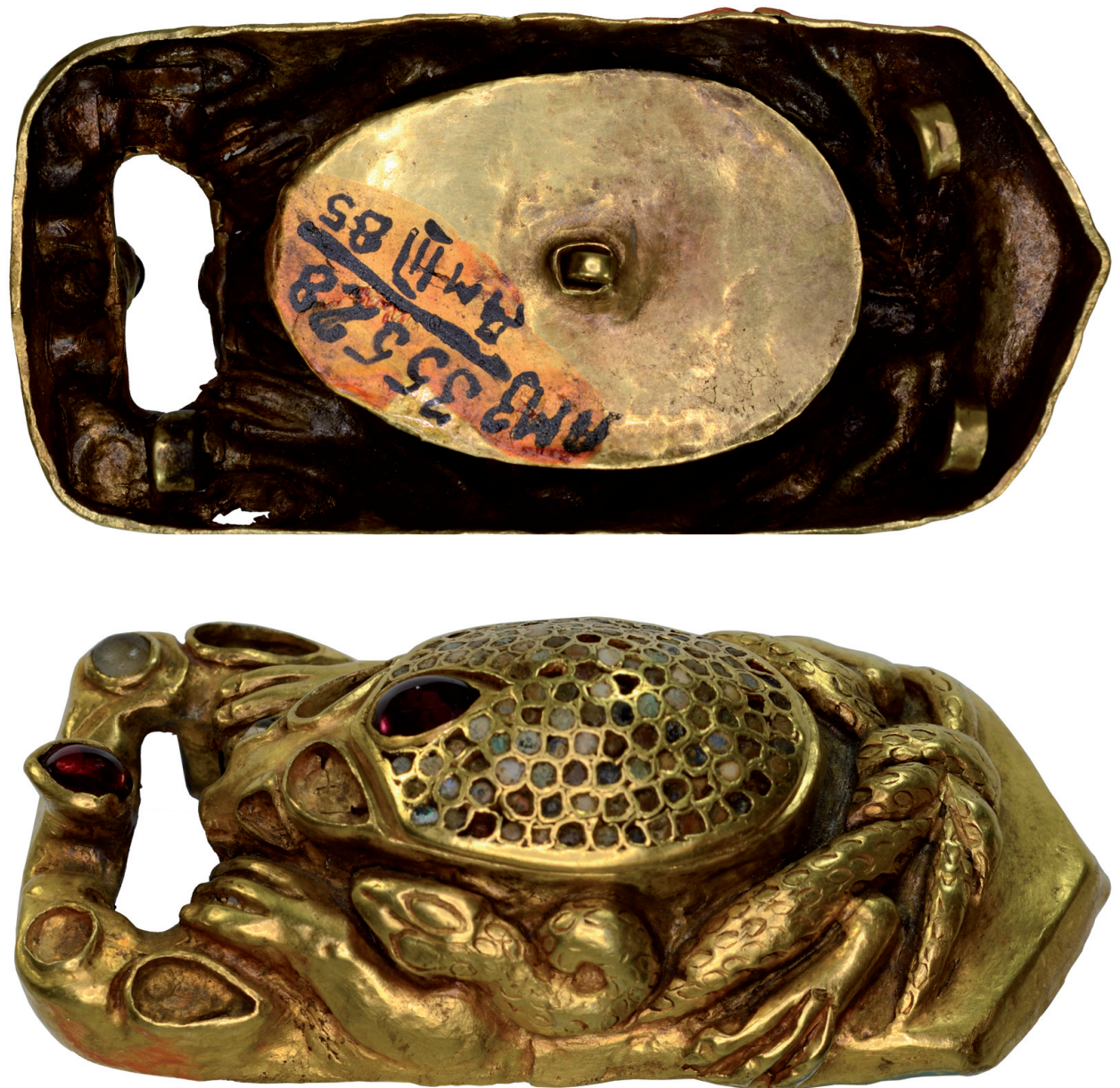

Рис. 3. Пряжка из погребения 1/1984 у с. Косика.

Астрахань, Государственный объединенный историко-архитектурный музей-заповедник, инв. № 35528 . Фотографии М.Ю. Трейстера

Fig. 3. The buckle from burial no. 1/1984 near the village of Kosika.

Astrakhan, State United Historical-Architectural Museum-Reserve, inventory no. 35528. Photographs by M. Treister 

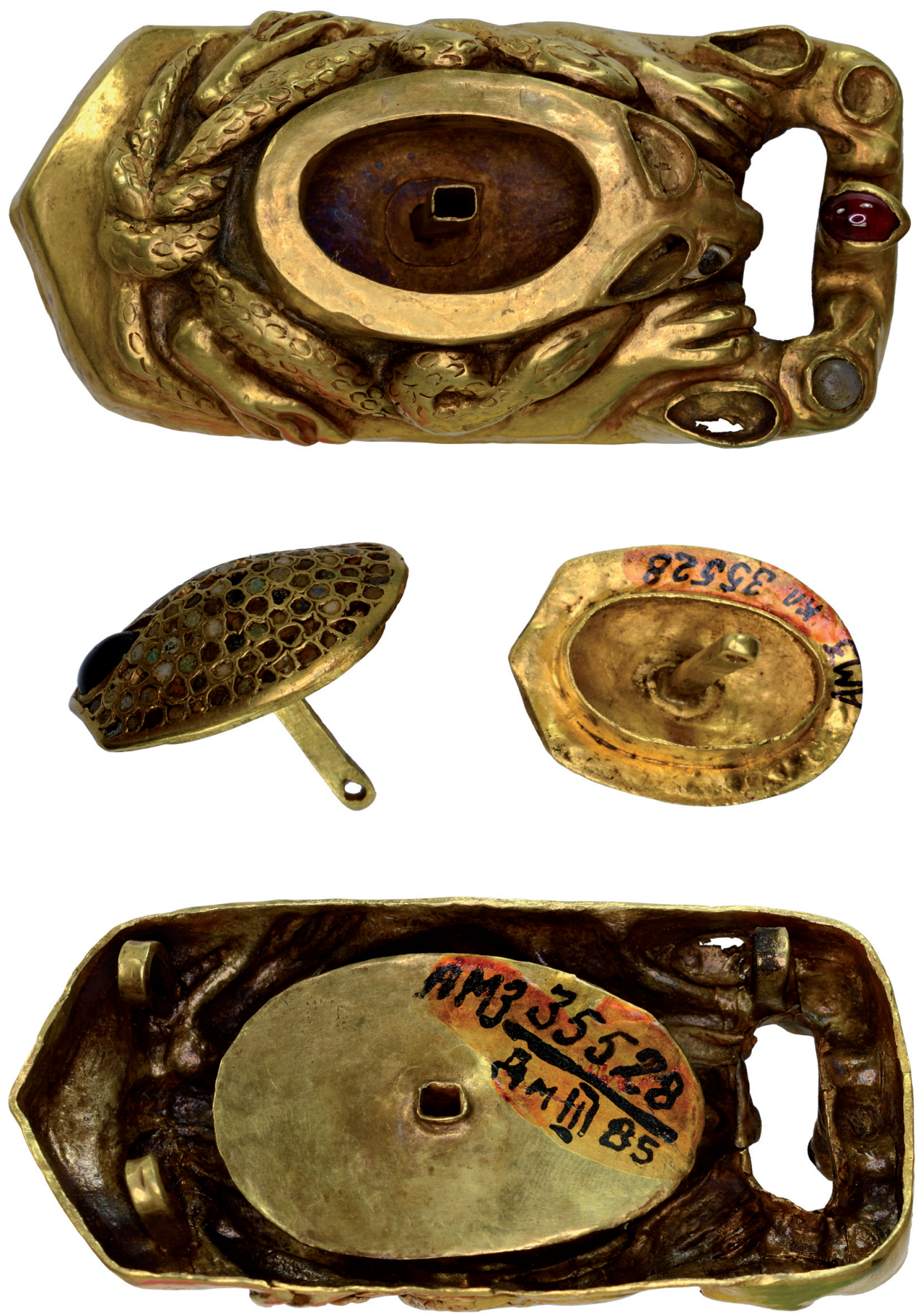

Рис. 4. Пряжка из погребения 1/1984 у с. Косика.

Астрахань, Государственный объединенный историко-архитектурный музей-заповедник, инв. № 35528. Фотографии М.Ю. Трейстера

Fig. 4. The buckle from burial no. 1/1984 near the village of Kosika.

Astrakhan, State United Historical-Architectural Museum-Reserve, inventory no. 35528.

Photographs by M. Treister 
M.Yu. Treister. A Precious Belt Set from the Nomadic Elite Burial near the Village of Kosika
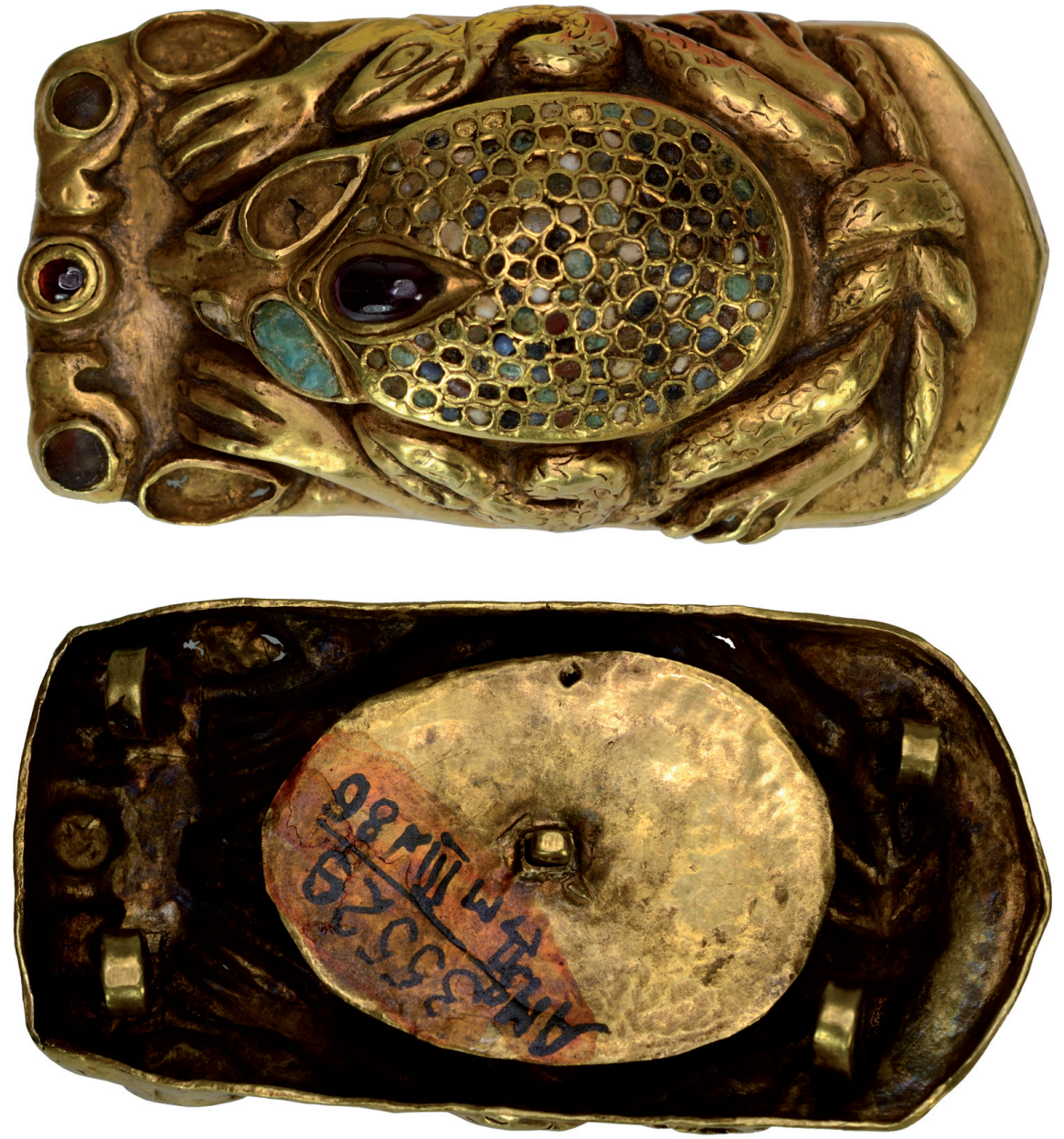

2

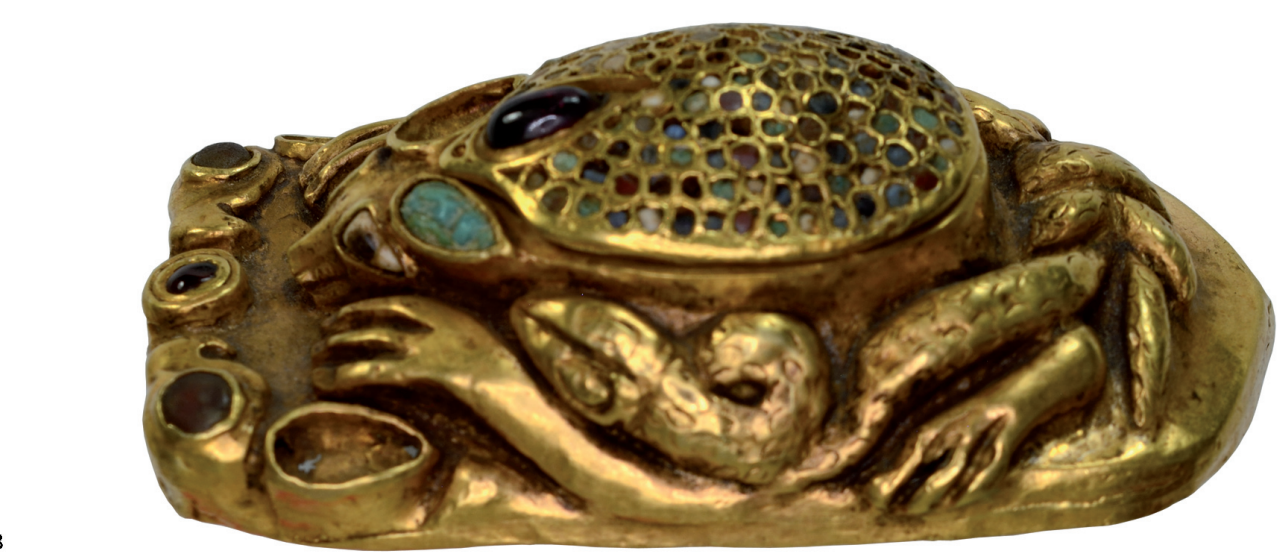

Рис. 5. Наконечник пояса из погребения 1/1984 у с. Косика.

Астрахань, Государственный объединенный историко-архитектурный музей-заповедник, инв. № 35529. Фотографии М.Ю. Трейстера

Fig. 5. The belt tip from burial no. 1/1984 near the village of Kosika.

Astrakhan, State United Historical-Architectural Museum-Reserve, inventory no. 35529.

Photographs by M. Treister 


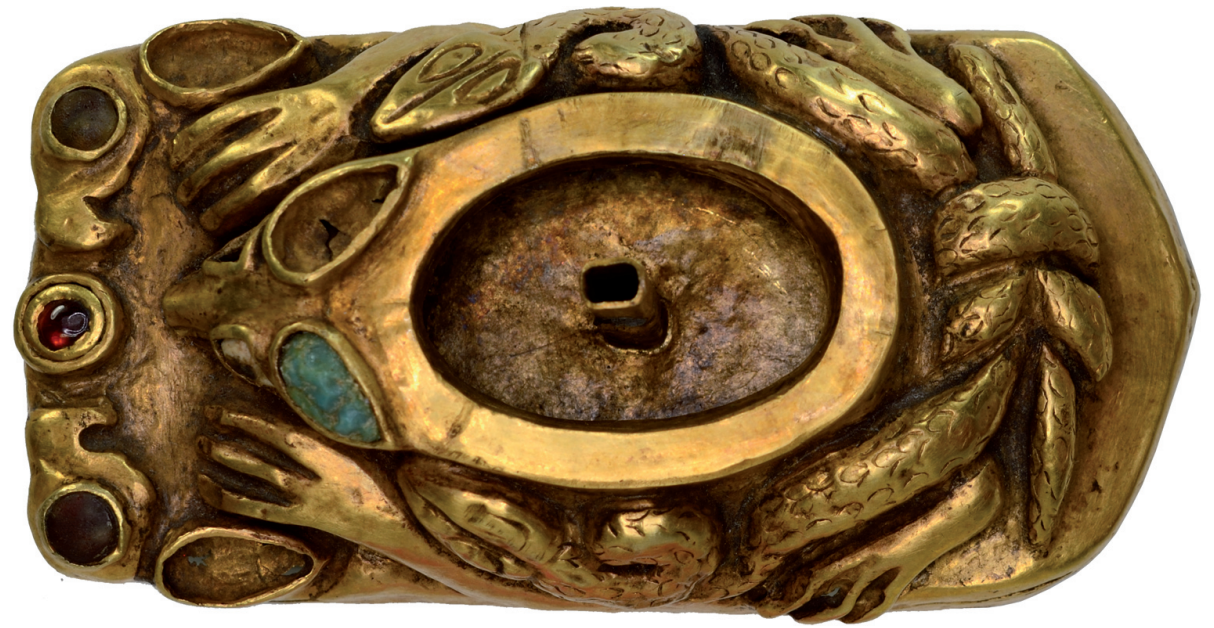

2
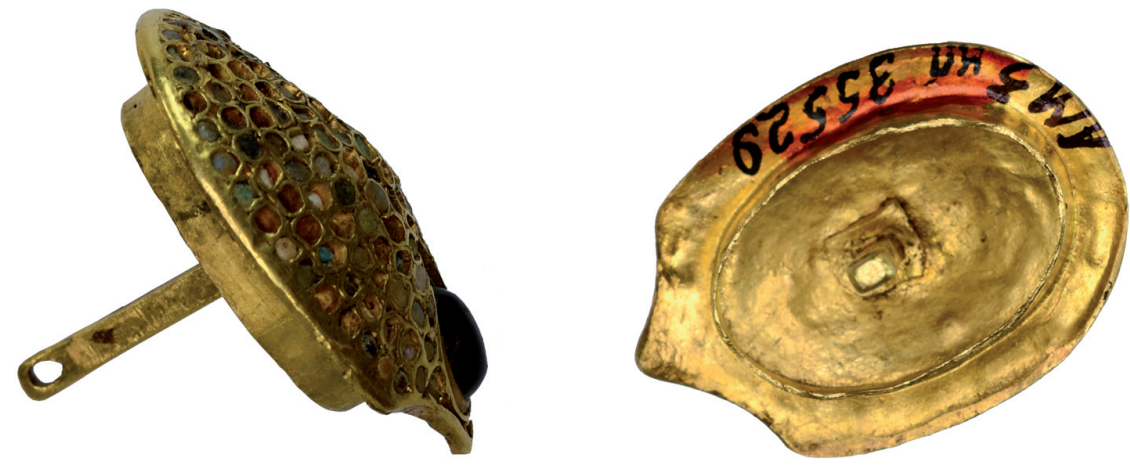

3

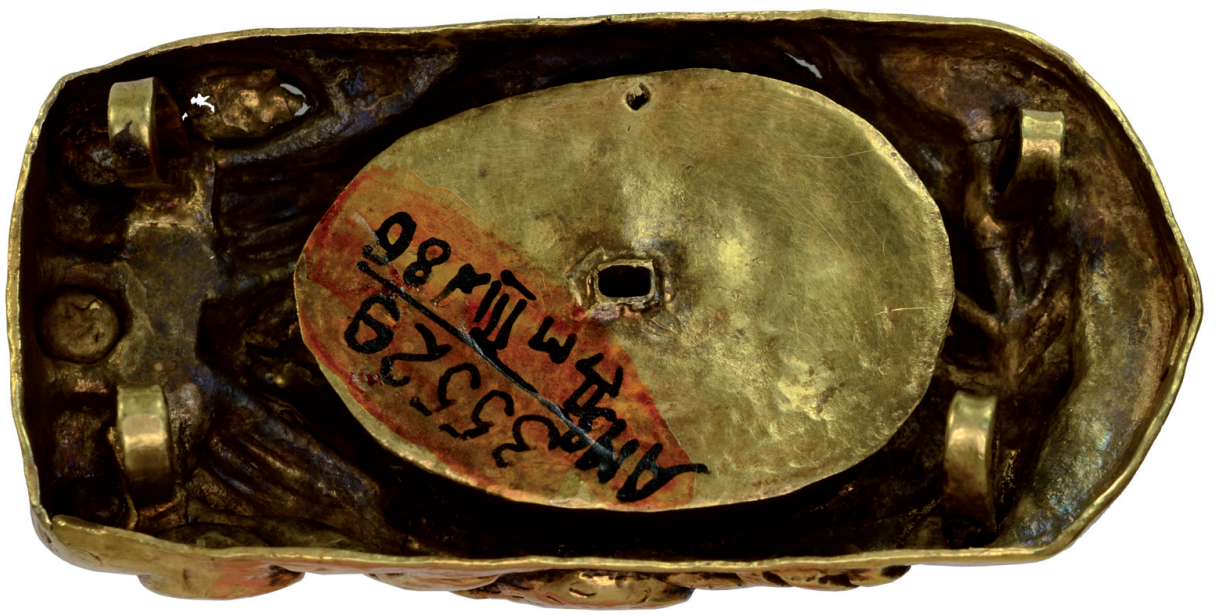

Рис. 6. Наконечник пояса из погребения 1/1984 у с. Косика.

Астрахань, Государственный объединенный историко-архитектурный музей-заповедник, инв. № 35529. Фотографии М.Ю. Трейстера

Fig. 6. The belt tip from burial no. 1/1984 near the village of Kosika.

Astrakhan, State United Historical-Architectural Museum-Reserve, inventory no. 35529.

Photographs by M. Treister 

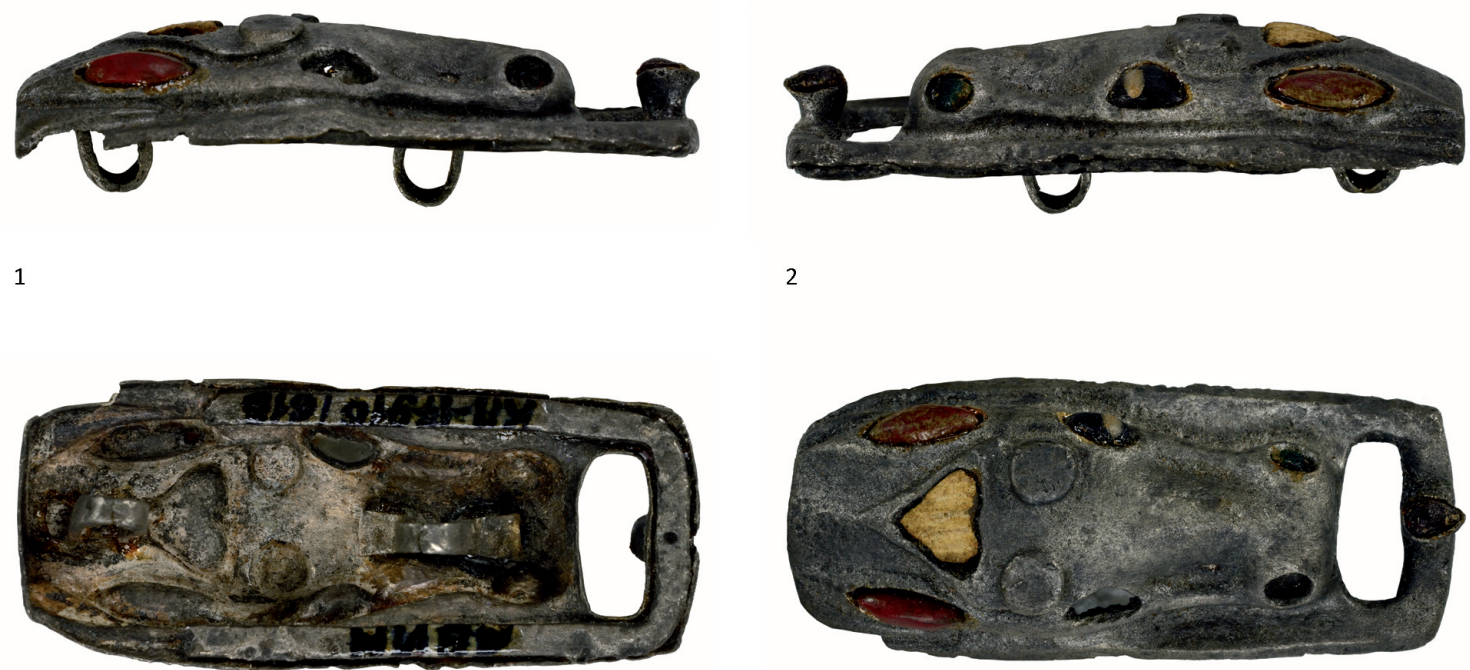

3

4
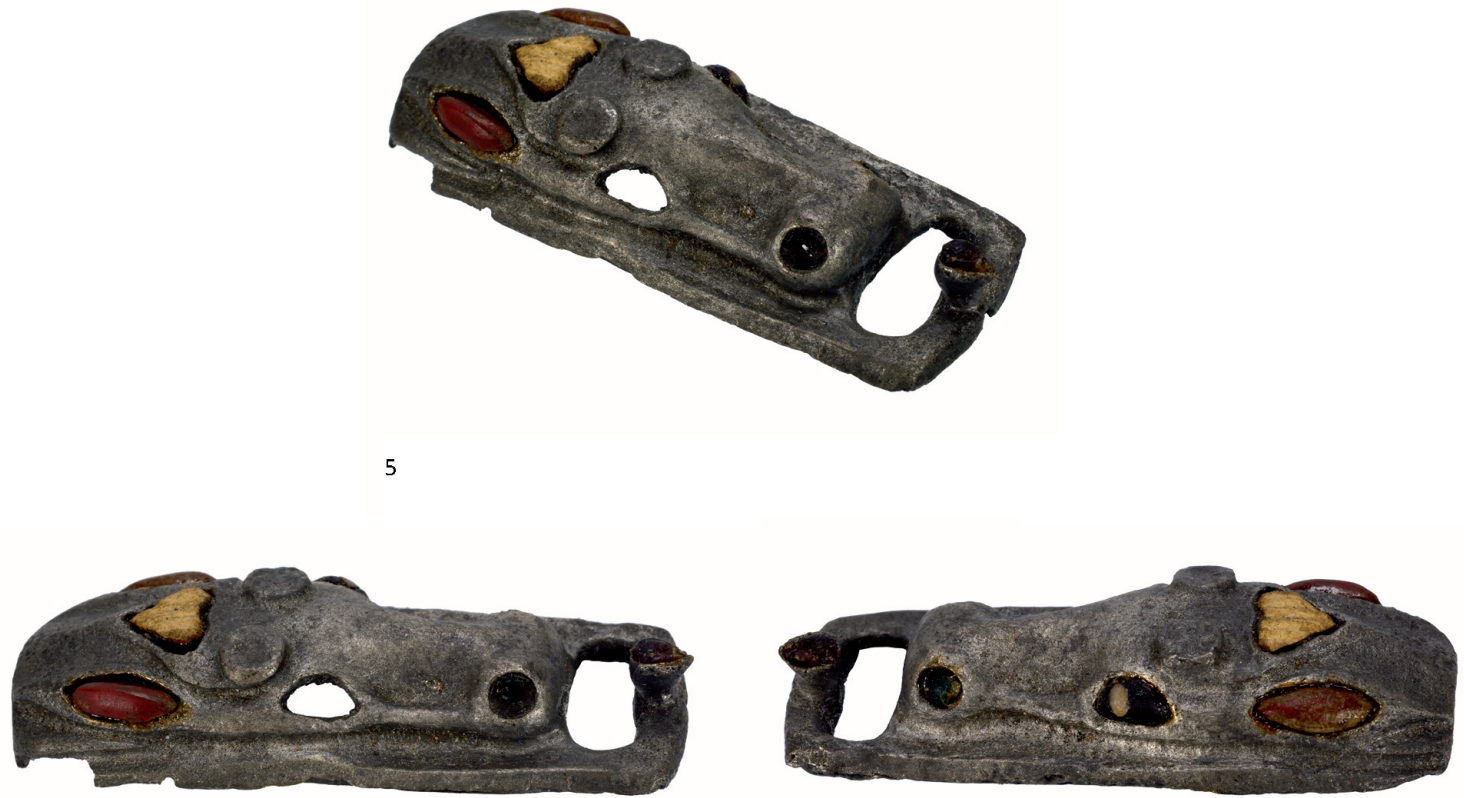

6

Рис. 7. Пряжка из погребения 2 кургана 20/1982 у хут. Новый. Аксай, Военно-исторический музей, инв. № 17910/613. Фотографии М.Ю. Трейстера

Fig. 7. The buckle from burial no. 2 of burial mound no. 20/1982 near the settlement of Novy. Aksai, Military-Historical Museum, inventory no. 17910/613.

Photographs by M. Treister 

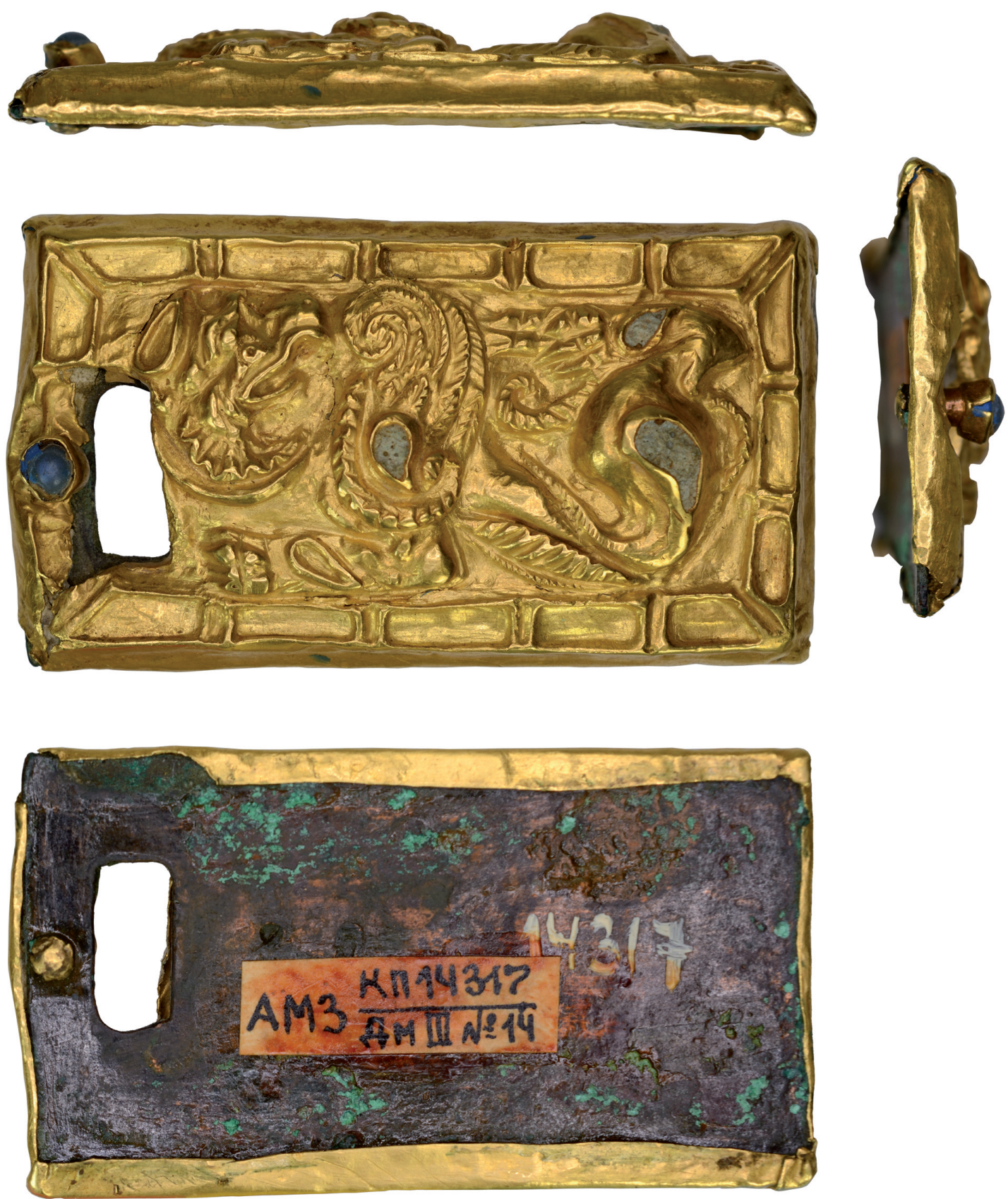

Рис. 8. Пряжка из погребения 1 кургана 12/1965 у с. Никольское.

Астрахань, Государственный объединенный историко-архитектурный музей-заповедник, инв. № 14317. Фотографии М.Ю. Трейстера

Fig. 8. The buckle from burial no. 1 of burial mound no. 12/1965 near the village of Nikolskoe. Astrakhan, State United Historical-Architectural Museum-Reserve, inventory no. 14317.

Photographs by M. Treister 
M.Yu. Treister. A Precious Belt Set from the Nomadic Elite Burial near the Village of Kosika

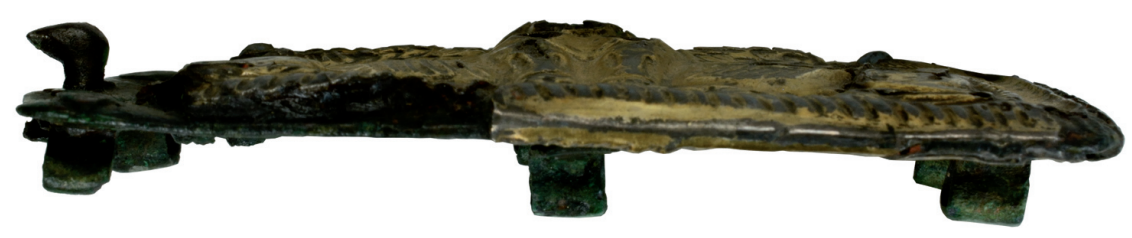

1
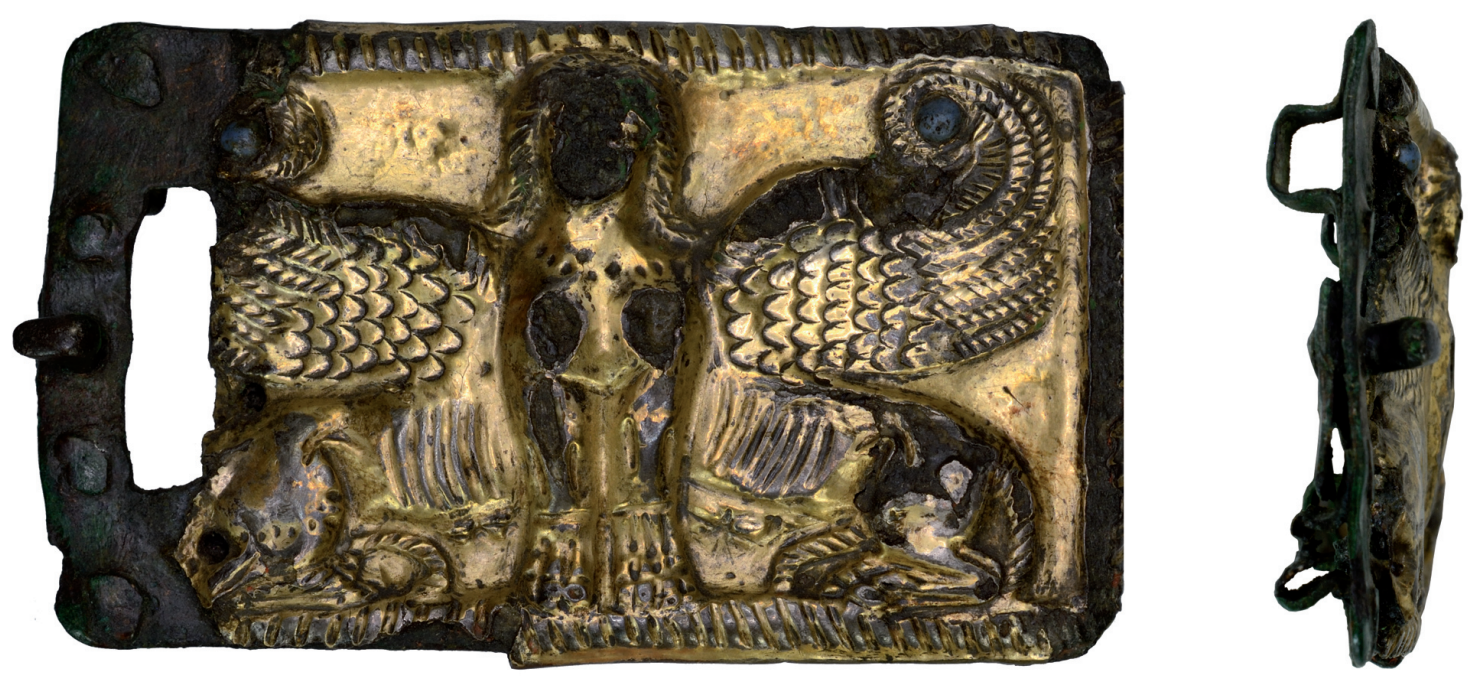

2

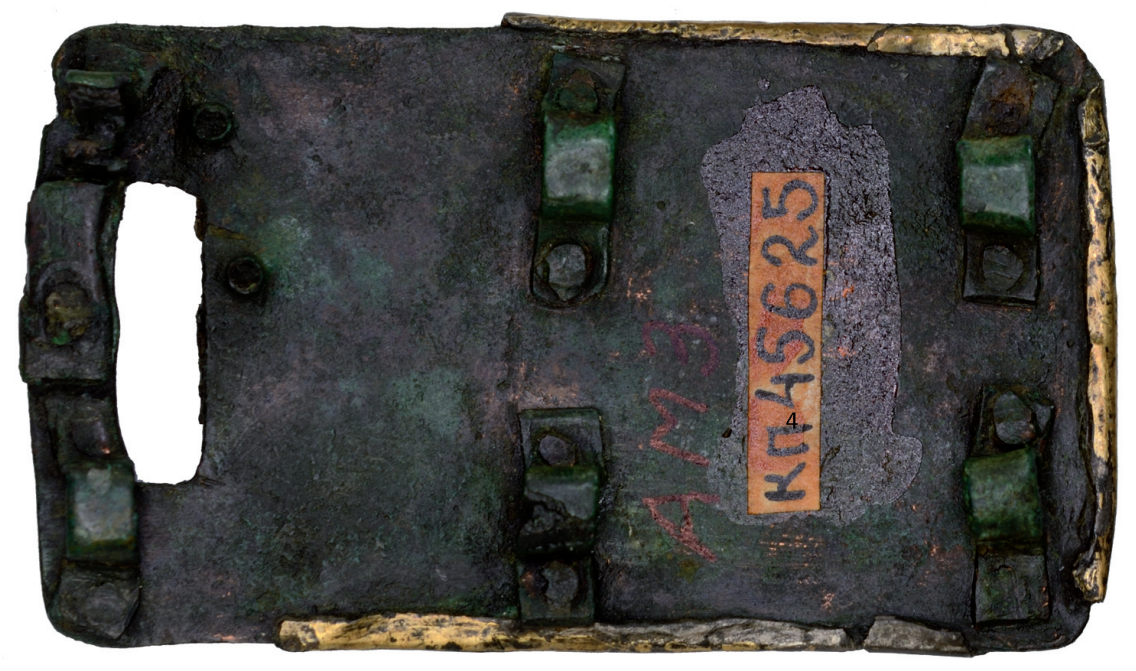

3

Рис. 9. Пряжка из погребения 1 кургана 13/1972 у с. Барановка.

Астрахань, Государственный объединенный историко-архитектурный музей-заповедник, инв. № 45625. Фотографии М.Ю. Трейстера

Fig. 9. The buckle from burial no. 1 of burial mound no. 13/1972 near the village of Baranovka. Astrakhan, State United Historical-Architectural Museum-Reserve, inventory no. 45625. Photographs by M. Treister 

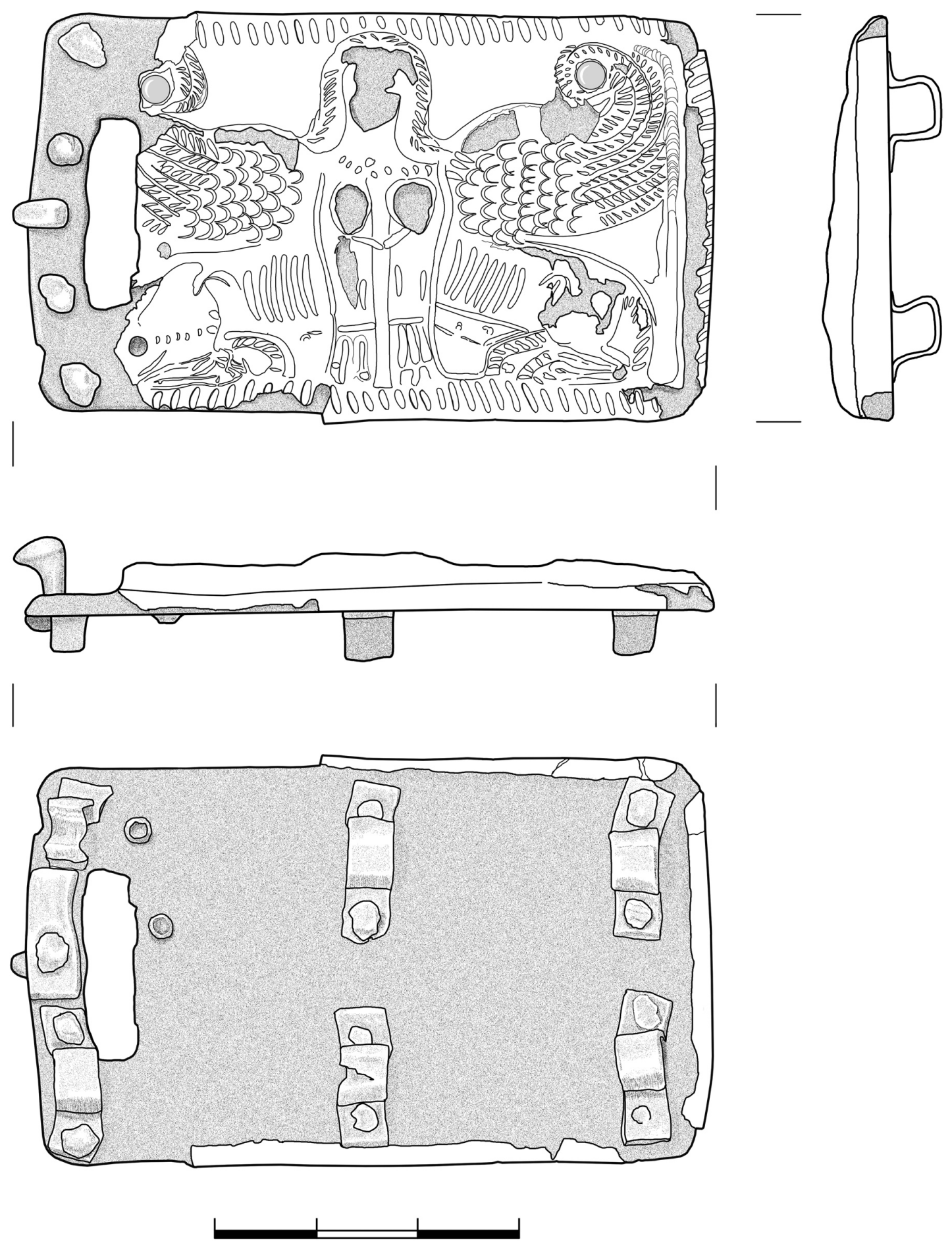

Рис. 10. Пряжка из погребения 1 кургана 13/1972 у с. Барановка. Рисунки Н.Е. Беспалой

Fig. 10. The buckle from burial no. 1 of burial mound no. 13/1972 near the village of Baranovka. Drawings by N.E. Bespalaya 

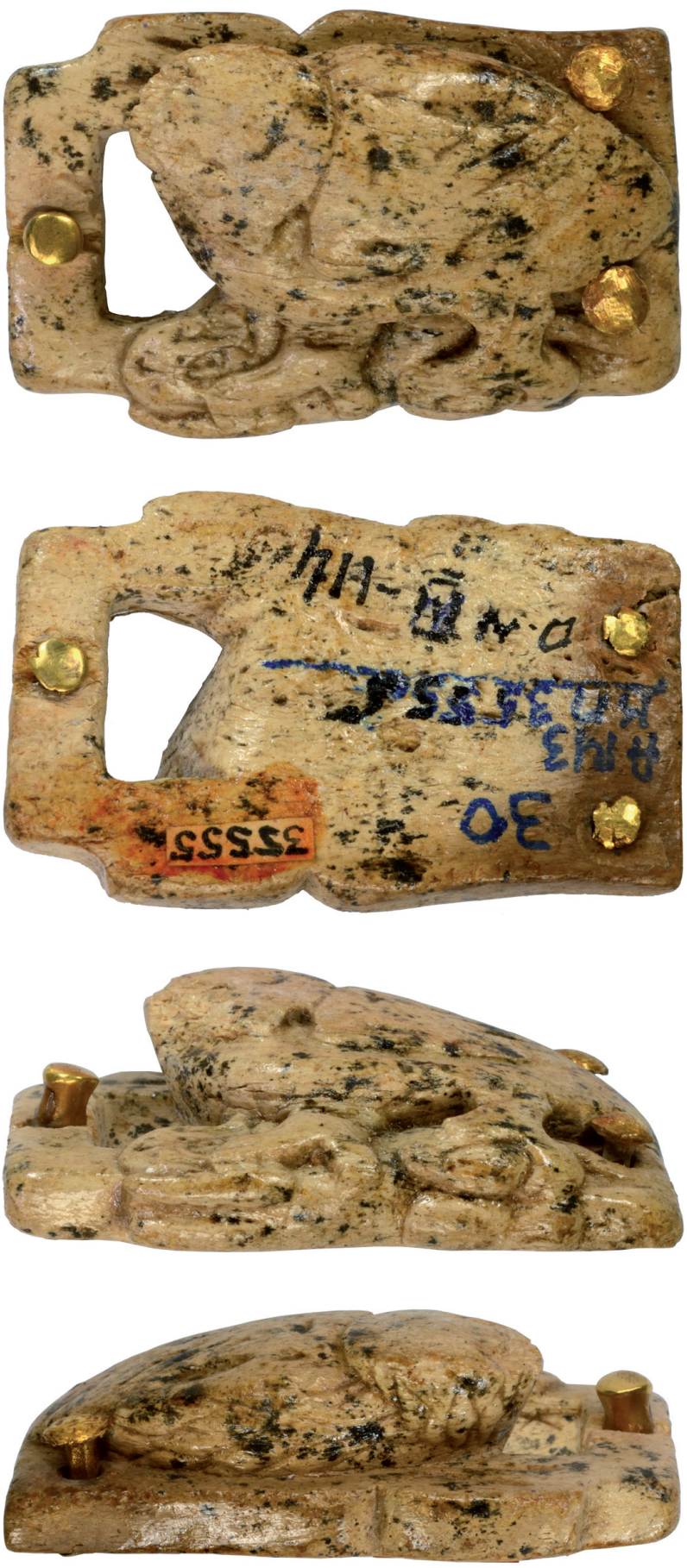

Рис. 11. Пряжка из погребения 1/1984 у с. Косика.

Астрахань, Государственный объединенный историко-архитектурный музей-заповедник, инв. № 35555. Фотографии М.Ю. Трейстера

Fig. 11. The buckle from burial no. 1/1984 near the village of Kosika.

Astrakhan, State United Historical-Architectural Museum-Reserve, inventory no. 35555.

Photographs by M. Treister 

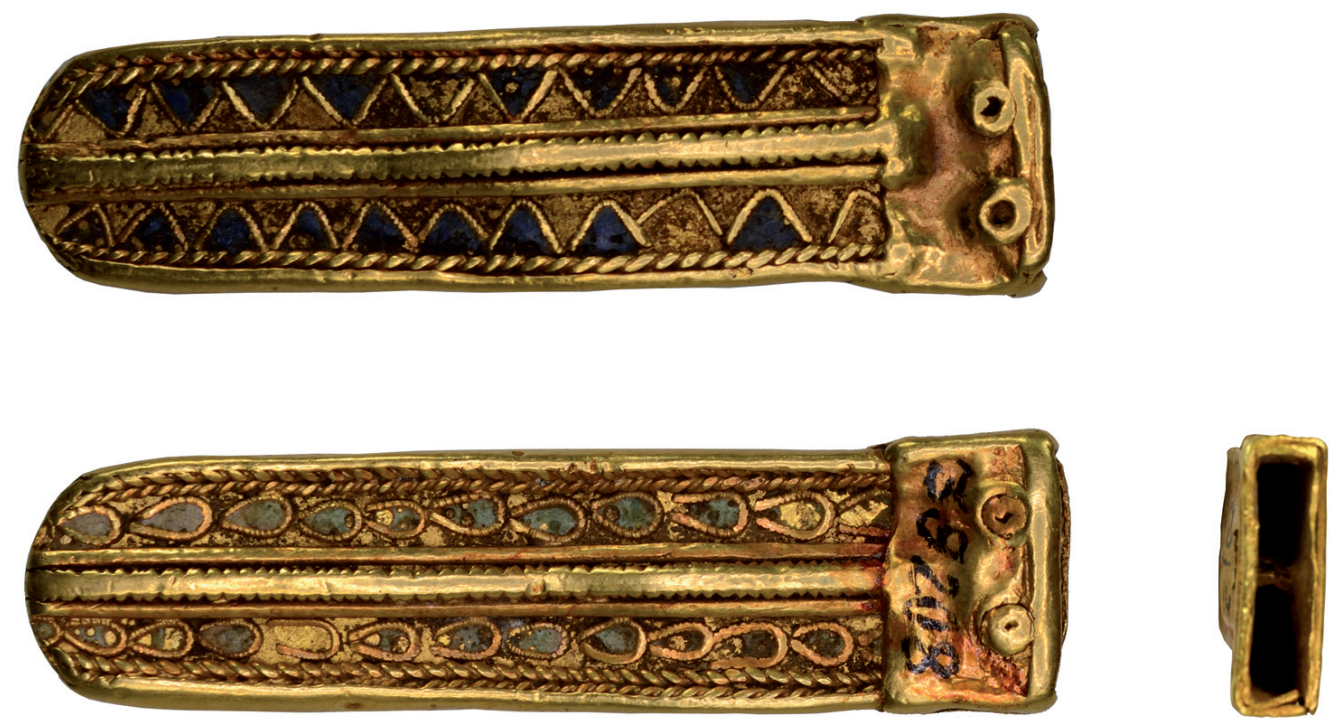

1
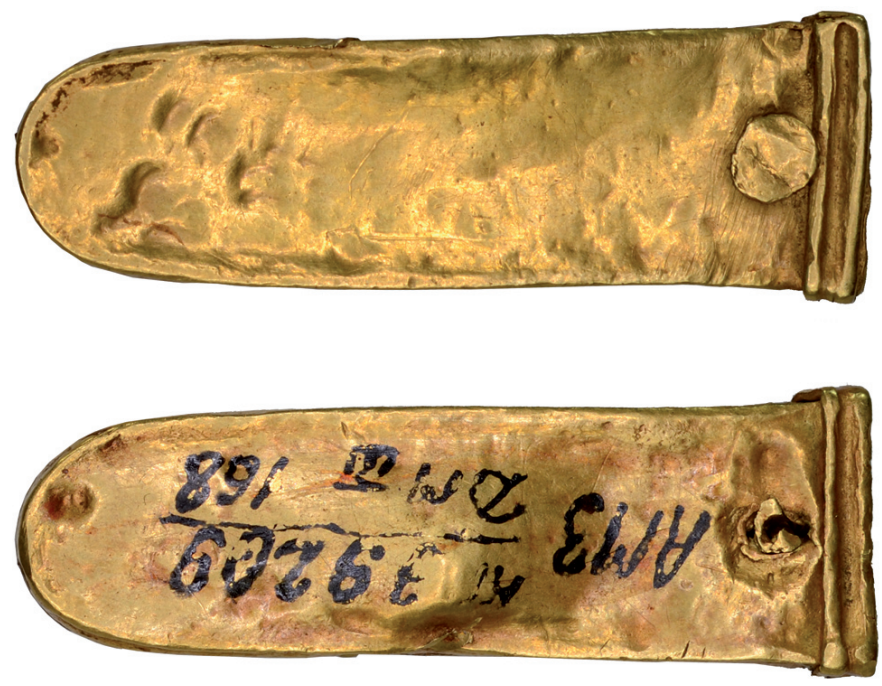

2

Рис. 12. Наконечники пояса из погребения 1/1984 у с. Косика.

Астрахань, Государственный объединенный историко-архитектурный музей-заповедник, инв. № 39208-39209. Фотографии М.Ю. Трейстера:

1 - № 39208; 2 - № 39209

Fig. 12. The belt tips from burial no. 1/1984 near the village of Kosika.

Astrakhan, State United Historical-Architectural Museum-Reserve, inventory nos. 39208-39209.

Photographs by M. Treister:

1 - no. 39208; 2 - no. 39209 


\section{ПРИМЕЧАНИЯ}

${ }^{1}$ Достаточно подробный обзор различных точек зрения как на датировку погребения, так и интерпретацию найденных в нем серебряных сосудов см.: [Туаллагов, 2013, с. 20-32; 2014, с. 47-64].

2 Представленная публикация выполнена в рамках проекта, финансируемого DFG и РГНФ «Формы и пути культурных контактов кочевников Азиатской Сарматии. Импорты в сарматских памятниках II в. до н.э. - III в. н.э.» (FL-334/15-1). Партнер проекта с российской стороны - Б.А. Раев, которому принадлежат цитируемые выше обмеры и описание сохранности предметов. Автор выражает искреннюю признательность за предоставленную нам возможность работать в фондах Музея и информацию о весе и пробах публикуемых предметов заведующей отделом фондов Музея Э.Р. Чиняковой.

${ }^{3}$ При этом пряжки из Северного Причерноморья, найденные преимущественно на Боспоре, отличаются не только сюжетами, но и конструктивно - прорези для ремня имеются и в передней (за крючком) и в задней части рамки [Rostovtzeff, 1931, S. 46-49, Taf. 1,1-8; Treister, 2003, p. 247-257; Трейстер, 2015, с. 295-296], а в задней части рамки нет характерного для парфянских пряжек шпенька.

4 Это не съемная деталь, как пишет В.И. Мордвинцева [2007, с. 229]. Странно, что В.И. Мордвинцева не обратила внимание на замечание В.В. Дворниченко и Г.А. Федорова-Давыдова [1993, с. 174] о том, что «по фотографии нельзя, к сожалению, определить, была ли верхняя часть съемной». В любом случае, в специальной публикации амулета из Еркургана [Рахманова, 1990, с. 83] нет ни слова о том, что перламутровая вставка на спинке ежа была съемной.

${ }^{5}$ Об изображениях ежа в искусстве номадов, обитавших на северных границах Китая, см.: [Cat. Washington, 1995, p. 94, no. 7; Psarras, 1995, p. 119 , 122, fig. 10; Bunker, 1997, p. 227, no. 175, p. 237, no. 192; Bunker et al., 2002, p. 87, no. 52].

${ }^{6}$ Пряжка из склепа № 620 Усть-Альминского могильника: [Loboda et al., 2002, S. 332, Nr. 11, Abb. 20,7; Puzdrovskij, 2013, S. 309, Nr. VII.41 (вставки бирюзы овальной и каплевидной формы на рамке и в центре узла)]. Пряжка из трупосожжения в серебряной урне, найденной Д.В. Карейшей в Керчи в 1842 г.: [Карейша, 1844, с. 617; ДБК, 1854, т. 2 , c. 220 ; т. 3, табл. ХХХІІ, 16; Толстой, Кондаков, 1889 , c. 154,156 , рис. 138 (вставки изумрудов овальной, округлой и каплевидной формы на рамке и на узле)]. Пряжка, приобретенная в 2003 г. Гос. Эрмитажем, с напаянными на рамку кастами со вставками гранатов: [Кат. Ст. Петербург, 2004, с. 56, № 63 (с датировкой II-III вв. н.э.)].
К этому же типу относится серебряная пряжка без вставок из погребения 1 кургана 11 могильника Каршинский на Нижнем Дону: [Кат. Новочеркасск, 1981, с. 31, № 318, табл. 6, 4; Максименко, 1998 , с. 244 , рис. 61,24$]$.

Более поздние версии пряжки с «узлом Геракла», представленные находками из Прикубанья [Гущина, Засецкая, 1994, с. 51, № 160, табл. 17; Абрамова, 1998 , с. 217 , рис. 3 , 14; Soupault-Becquelin, 1999, p. 301, fig. 2, 1; Гущина, Засецкая, 1994, с. 47, № 91, табл. 10; Абрамова, 1998, с. 217, рис. 3, 12], имеют подвижный язычок вместо крючка.

${ }^{7}$ На это уже обращалось внимание [Abdullaev, 2008, p. 138].

${ }^{8}$ Нет сомнений в том, что этот фалар в 1960-е гг. находился в тегеранском собрании Азизбеглу и, по сообщениям, был найден к юго-западу от Каспийского моря (то есть на территории Иранского Азербайджана. - M. T.) [Ghirshman, 1969, p. 9-17; Farkas, 1973, p. 80, fig. 5, p. 81]. Парный фалар оказался вначале в собрании Н.М. Хеераманека, а затем в коллекции Музея искусства в Лос-Анжелесе [Cat. Los Angeles, 1981, p. 181, no. 936]. О сходстве фаларов из Косики и Музея Барбье-Мюллера см.: [Treister, 1997, p. 52; Treister, Yatsenko, 1998, p. 5960, 71-72].

${ }^{9}$ См. также подобные серьги с аналогичной конструкцией кастов со вставками изумрудов и гранатов в Музее Бенаки [Delivorrias, 1999, p. 230-231, no. 81, fig. 165] и из клада «в квартале ювелиров», найденного на Делосе в 1964 г. [Hackens, Lévy, 1965, p. 541-547, fig. 6, pls. 17, 20; LIMC III, 1986, s.v. Eros (A. Hermary, H. Cassimatis, R. Vollkommer), p. 909, no. 672 a; Zafeiropoulou, 1998 , p. 295, no. 256].

\section{СПИСОК ЛИТЕРАТУРЫ}

Абдуллаев К., 2011. Парфянские мотивы в настенной росписи нахшеба (Еркурган и его округа) // Un impaziente desiderio di scorrere il mondo. Studi in onore di Antonio Invernizzi per il suo settantesimo compleanno (Monografie di Mesopotamia XIV). Firenze: Casa Editrice "LeLettere". P. 309-320.

Абрамова М. П., 1998. Хронологические особенности северокавказских пряжек первых веков нашей эры // Материалы по археологии и этнографии Таврии. Вып. VI. Симферополь. С. 209-229.

Артамонов М. И., 1973. Сокровища саков. М. : Искусство. 280 с.

Археологическое наследие, 2013. Археологическое наследие Волгоградской области. К 100-летию Волгоградского областного краеведческого музея. Волгоград : Издатель. 288 с.

Беспалый Е. И., 1992. Курган сарматского времени у г. Азова// Советская археология. № 1. С. 175-190. 
Виноградов Ю. Г., 1994. Очерк военно-политической истории сарматов в I в. н.э. // Вестник древней истории. № 2. С. 151-170.

Власкин М. В., 1989. Золотые зооморфные пряжки из курганного могильника у х. Нового // Историко-археологические исследования в г. Азове и на Нижнем Дону в 1988 году : (тез. докл. к семинару). Азов : Краеведческий музей. С. 29-37.

Глебов В. П., 2016. Пряжки с зооморфными изображениями в раннесарматской культуре Нижнего Подонья // Константин Федорович Смирнов и современные проблемы сарматской археологии : материалы IX Междунар. науч. конф. «Проблемы сарматской археологии и истории», посвящ. 100-летию со дня рождения Константина Федоровича Смирнова. Оренбург : Изд-во ОГПУ. С. 69-79.

Гордин И. А., 1989. Отчет об археологических раскопках курганов у с. Чалтырь из курганного могильника «Хапры» в зоне строительства орошаемого участка Мясниковского района Ростовской области в 1988 г. Азов // Архив ИА РАН. № Р-1. 12939-12940.

Гущина И. И., Засецкая И. П., 1994. «Золотое кладбище» римской эпохи в Прикубанье. СПб. : Фарн. 172 c.

ДБК, 1854. Древности Босфора Киммерийского, хранящиеся в Императорском музее Эрмитажа. T. II. Спб. : в типографии Императорской Академии наук. Т. 1. 279 с. ; Т. 2. 339 с. ; Т. 3.236 с., 86 табл., планы, карты.

Дворниченко В. В., Федоров-Давыдов Г. А., 1989. Памятники сарматской аристократии в Нижнем Поволжье // Сокровища сарматских вождей и древние города Поволжья. М. : Наука. C. 5-13.

Дворниченко В. В., Федоров-Давыдов Г. А., 1993. Сарматское погребение скептуха I в. н.э. у с. Косика Астраханской области // Вестник древней истории. № 3. С. 141-179.

Древнейшие государства, 1985. Древнейшие государства Кавказа и Средней Азии (Археология СССР). М. : Наука. 496 с.

Засецкая И. П., 1979. Савроматские и сарматские погребения Никольского могильника в Нижнем Поволжье // Тр. Гос. Эрмитажа. Вып. XX. C. 87-113.

Засецкая И. П., 2012а. Изображения грифонов и «грифов» в сарматском зверином стиле // Золото, конь и человек : сб. ст. к 60-летию Александра Владимировича Симоненко. Киев : КНТ. С. $353-383$.

Засецкая И. П., 2012б. Образ волка в сарматском искусстве I в. н.э. // Вояджер: мир и человек: теорет. и науч.-метод. журн. Вып. 3. Самара. C. $63-73$.
Засецкая И. П., 2013. Значение вещей сарматского полихромного звериного стиля в погребальном обряде I века новой эры // Археологический сборник Государственного Эрмитажа. Вып. 39. С. 138-147.

Ильюков Л. С., Власкин М. В., 1992. Сарматы междуречья Сала и Маныча. Ростов н/Д : Изд-во Рост. гос. ун-та. 288 с.

Карейша Д. В., 1844. Разрытие курганов возле Керчи и Тамани в 1842 и в начале 1843 года // Записки Одесского Общества истории и древностей. T. 1. С. 609-620.

Кат. Новочеркасск, 1981. Новочеркасский музей истории донского казачества. Каталог выставки новых поступлений отдела археологии (1970-1980 гг.). Новочеркасск : Музей истории донского казачества. 80 с.

Кат. Ст. Петербург, 2004. Иран в Эрмитаже. Формирование коллекций. СПб. : Славия. 255 с.

Кат. Ст. Петербург, 2008. Сокровища сарматов. Каталог выставки. К 100-летию со дня рождения Б.Б. Пиотровского. СПб. ; Азов : Изд-во Азов. историко-археол. и палеонтол. музея-заповедника. $176 \mathrm{c}$.

Клепиков В. М., 2002. Сарматы Нижнего Поволжья в IV-III вв. до н.э. Волгоград : Изд-во ВолГУ. $216 \mathrm{c}$.

Королькова Е. Ф., 2006. Звериный стиль Евразии. Искусство племен Нижнего Поволжья и Южного Приуралья в скифскую эпоху (VIIIV вв. до н.э.). СПб. : Петербургское востоковедение. $272 \mathrm{c}$.

Максименко В. Е., 1998. Сарматы на Дону (археология и проблемы этнической истории) (Донские древности 6). Азов : Изд-во Азов. краевед. музея. 304 с.

Малашев В. Ю., Дзуцев Ф. С., 2016. Парадные сбруйные наборы III в. н.э. из Бесланского могильника и проблема сложения аланской культуры Северного Кавказа // Малашев В.Ю. Памятники среднесарматской культуры северокавказских степей и их традиции в курганных могильниках Северо-Восточного Кавказа второй половины II - середины V в. н.э. М. : ИА PAH. C. 160-177.

Мамонтов В. И., 2000. Древнее население левобережья Дона (по материалам могильника Первомайский VII). Волгоград : Изд-во ВолГУ. $145 \mathrm{c}$.

Матющенко В. И., Татаурова Л. В., 1997. Могильник Сидоровка в Омском Прииртышье. Новосибирск : Наука. 197 с.

Миняев С. С., 1995. Новейшие находки художественной бронзы и проблема формирования геометрического стиля в искусстве сюнну // Археологические вести. Вып. 4. С. 123-136. 
Мордвинцева В. И., 2003. Полихромный звериный стиль. Симферополь : Универсум. 216 с.

Мордвинцева В. И., 2007. Сарматский полихромный звериный стиль // Мордвинцева В. И., Трейстер М. Ю. Произведения торевтики и ювелирного искусства в Северном Причерноморье. II в. до н.э. - II в. н.э. Т. І. Симферополь ; Бонн : Тарпан. С. 195-244.

Мордвинцева В. И., Мыськов Е. П., 1999. Курганы сарматской знати у поселка Октябрьский // Археологические вести. Вып. 6. С. 179-191.

Мордвинцева В. И., Трейстер М. Ю., 2007. Произведения торевтики и ювелирного искусства в Северном Причерноморье. II в. до н.э. - II в. н.э. В 3 т. Т. II. Симферополь ; Бонн : Тарпан. $255 \mathrm{c}$.

Мошкова М. Г., 1960. Раннесарматские бронзовые пряжки // Древности Нижнего Поволжья. T. II : (Итоги работ Сталинградской археологической экспедиции) (МИА. Т. 78). М. : Наука. С. 293-307.

Рахманова С. И., 1990. Амулет из Еркургана // Археология Средней Азии : тез. докл. Ташкент : Изд-во Ташкент. гос. ун-та. С. 83.

Симоненко А. В., 2015. Сарматские всадники Северного Причерноморья. 2-е изд. Киев : Издатель Олег Филюк. 466 с.

Симоненко А. В., Лобай Б. И., 1991. Сарматы Северо-Западного Причерноморья в I в. н.э. Киев : Наукова думка. 108 с.

Скрипкин А. С., 1990. Азиатская Сарматия. Проблемы хронологии и ее исторический аспект. Саратов : Изд-во Сарат. ун-та. 303 с.

Скрипкин А. С., 2000. Новые аспекты в изучении истории материальной культуры сарматов // Нижневолжский археологический вестник. Вып. 3. С. 17-40.

Скрипкин А. С., 2006. К проблеме соотношения ранне- и среднесарматской культур // Раннесарматская и среднесарматская культуры: проблемы соотношения. Вып. 1. Волгоград : Волгогр. науч. изд-во. С. 5-27.

Смирнов А. П., 1940. Новый сарматский могильник в Воронежской области // Вестник древней истории. № 3-4. С. 363-366.

Спицын А. А., 1909. Фалары Южной России // Известия императорской археологической комиссии. Вып. 29. С. 18-53.

Сулейманов Р. Х., 2000. Древний Нахшаб. Ташкент : Фан. 338 с.

Толстой И. И., Кондаков Н. П., 1889. Древности скифо-сарматские : (Русские древности в памятниках искусства. Т. 2). СПб. : Тип. М-ва путей сообщения. $161 \mathrm{c}$.

Трейстер М. Ю., 1994. Сарматская школа художественной торевтики : (К открытию сервиза из
Косики) // Вестник древней истории. № 3. C. 172-203.

Трейстер М. Ю., 2007а. Типы накладных пластинчатых кастов, форма, материал и цвет вставок // Мордвинцева В. И., Трейстер М. Ю. Произведения торевтики и ювелирного искусства в Северном Причерноморье. ІІ в. до н.э. II в. н.э. Т. І. Симферополь ; Бонн : Тарпан. C. 272-287.

Трейстер М. Ю., 2007б. Клуазонне // Мордвинцева В. И., Трейстер М. Ю. Произведения торевтики и ювелирного искусства в Северном Причерноморье. II в. до н.э. - II в. н.э. Т. I. Симферополь ; Бонн : Тарпан. С. 288-294.

Трейстер М. Ю., 2007в. Вставки гемм (за исключением перстней) // Мордвинцева В. И., Трейстер М. Ю. Произведения торевтики и ювелирного искусства в Северном Причерноморье. II в. до н.э. - II в. н.э. Т. І. Симферополь ; Бонн : Тарпан. С. 295-305.

Трейстер М. Ю., 2015. Воин в доспехе, коронуемый Никой, в монументальном искусстве Боспора первых веков н.э. : (Кто изображен на рельефах из Пантикапея и Танаиса?) // С Митридата дует ветер. Боспор и Причерноморье в античности. К 70-летию В. П. Толстикова. М. : Университет Дмитрия Пожарского. С. 288-304.

Туаллагов А. А., 2013. Аланы и некоторые данные эпиграфических памятников // Известия Северо-Осетинского Института гуманитарных и социальных исследований. Вып. 9 (48). С. 20-32.

Туаллагов А. А., 2014. Аланы Придарьялья и закавказские походы I-II вв. Владикавказ : ИПЦ Северо-Осетинского Института гуманитарных и социальных исследований Владикавказского научного центра РАН и Республики Северная Осетия - Алания. 230 с.

Штейн В. Ф., 1968. Пряжка с изображением ежей из Сибирской коллекции Эрмитажа // Советская археология. № 2. С. 269-272.

Яценко С. А., 2000. О мнимых «бактрийских» ювелирных изделиях в Сарматии I-II вв. н.э. // Нижневолжский археологический вестник. Вып. 3. С. $172-185$.

Abdullaev K. A., 2008. Bactrian Gold Buckle with the Contest Between a Hero and a Centaur (Herakles and Nessos?) // Parthica. Vol. 10. P. 135-149.

Baumer C., 2012. The History of Central Asia: The Age of the Steppe Warriors. New York : I.B.Tauris \& Co. Ltd. 384 p.

Bernard P., Bopearachchi O., 2002. Deux bracelets grecs avec inscriptions grecques trouvés dans l'Asie centrale hellénisée // Journal des savants. P. 237-278.

Boardman J., 2010. The ReliefPlaques of Eastern Eurasia and China. The 'Ordos Bronzes', Peter the Great's 
Treasure, and their kin (Beazley Archive Occasional Paper). Oxford : Archaeopress. 103 p.

Boardman J., 2012. Tillya Tepe: Echoes of Greece and China // Afghanistan: Forging Civilizations along the Silk Road (The Metropolitan Museum of Arts Symposia). New York : The Metropolitan Museum of Art. P. 102-111.

Boardman J., 2015. The Greeks in Asia. London : Thames and Hudson Ltd. 240 p.

Brosseder U., 2011. Belt Plaques as an Indicator of East-West Relations in the Eurasian Steppe at the Turn of the Millennia // Xiongnu Archaeology. Multidisciplinary Perspectives of the First Steppe Empire in Inner Asia (Bonn Contributions to Asian Archaeology, 5). Bonn : Vor- und Frühgeschichtliche Archäologie, Rheinische Friedrich-Wilhelms-Universität Bonn. P. 349-424.

Bunker E.C., 1997. Ancient Bronzes of the Eastern Eurasian Steppes from the Arthur M. Sackler Collection. New York : Arthur M. Sackler Foundation. $401 \mathrm{p}$.

Bunker E. C., Watt Y. C. Y., Zhisun Sun, 2002. Nomadic Art of the Eastern Eurasian Steppes. The Eugene V. Thaw and Other New York Collections. New York ; New Haven ; London : Yale University Press. 320 p.

Cat. Daoulas, 1995. Entre Asie et Europe. L'or des Sarmates. Nomades des steppes dans l'antiquité. 17 juin - 29 octobre 1995. Abbaye de Daoulas: Centre culturel Abbaye de Daoulas. 141 p.

Cat. Los Angeles, 1981. Moorey P. R. S., Bunker E. C., Porada E., Markoe G. Ancient Bronzes, Ceramics and Seals. The Nasli M. Heeramaneck Collection of Ancient Near Eastern, Central Asiatic, and European Art. Los Angeles County Museum. Los Angeles : Los Angeles County Museum of Art. $271 \mathrm{p}$.

Cat. Milan, 1995. Tesori delle Steppe. Cimmeri, Sciti, Sarmati, Unni, Avari e Cazari. Milano : Galleria Ottavo Piano, La Rinascente. 210 p.

Cat. New York, 1990. Glories of the Past. Ancient Art from the Shelby White and Leon Levy Collection.The Metropolitan Museum of Art. New York : The Metropolitan Museum of Art. $280 \mathrm{p}$.

Cat. New York, 2000. The Year One. Art of the Ancient World. East and West. New York : The Metropolitan Museum of Art.192 p.

Cat. Paris, 1961. Sept mille ans d'art en Iran. Paris : Les Presses artistiques. 209 p.

Cat. Paris, 2000. L'Asie des steppes d'Alexandre le Grand à Gengis Khån. Paris : Réunion des musées nationaux. 202 p.

Cat. Paris, 2001. L'or des Amazones. Paris : Editions Findakly/Paris musées. 300 p.
Cat. Rome, 2005. I Tesori della steppa di Astrakhan. Milano: Mondadori Electa. $183 \mathrm{p}$.

Cat. Tokyo, 1991. The Treasures of Nomadic Tribes in South Russia. Tokyo : Ancient Orient Museum. $178 \mathrm{p}$.

Cat. Washington, 1995. So J. F., Bunker E. C. Traders and Raiders on China's Northern Frontier. Seattle, London : Smithsonian Institution, in association with University of Washington Press. 203 p.

Collon D., 1995. British Museum. Ancient Near Eastern Art. London : University of California Press. 247 p.

Curtis V. S., 2001. Parthian Belts and Belt Plaques // Iranica antiqua. Vol. XXXVI. P. 299-327.

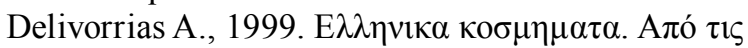

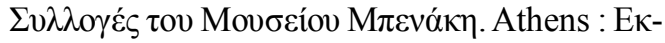

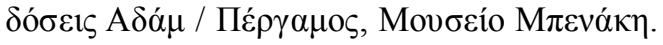
510 p. (in Greek).

Di Cosmo N., 1999. The Northern Frontier in PreImperial China // The Cambridge History of Ancient China. Cambridge : Cambridge University Press. P. 885-966.

Dvornitchenko V. V., Fedorov-Davydov G. A., 1994. Trésors des tombes de l'aristocratie sarmate au nord de la Caspienne // Les dossiers d'archéologie. № 194. P. 66-75.

Farkas A., 1973. Sarmatian Roundels and Sarmatian Art // The Metropolitan Museum of Art Journal. Vol. 8. P. 77-88.

Fedorov-Davydov G. A., 2001. The Silk Road and the Cities of the Golden Horde. Berkeley : Zinat Press. 189 p.

Ghirshman R. 1962. Iran. Parther und Sasaniden. München : C.H. Beck. 404 S.

Ghirshman R., 1969. Disque en bronze a decor ternaire //Forschungen zur Kunst Asiens: In memoriam Kurt Erdmann. Istanbul : Istanbul Üniversitesi Edebiyat Fakültesi, Türk ve Isläm Sanati Kürsüsü. P. 9-17.

Ghirshman R., 1979. La ceinture en Iran // Iranica antiqua. Vol. 14. P. 166-196.

Gift..., 1985. Gift of Keith P. Smith 1985.180: Западная Азия. Electronic text data. Mode of access: https://www.clevelandart.org/art/1985.180?f\%5 B0 $\% 5 \mathrm{D}=$ field_art_credit_line $\% 3 \mathrm{AGift} \% 20 \mathrm{of} \%$ 20Keith\%20P.\%20Smith (date of access: 12.04.2018). Title from screen.

Hackens T., Lévy E., 1965. Trésor hellénistique trouvé à Délos en 1964 // Bulletin de correspondence hellénique. Vol. 89. P. 503-566.

Herzfeld E. B., 1928. The Hoard of the Karen Pahlavs // Burlington Magazine. Vol. 53. P. 21-27.

Hickman J., 2012. Bactrian Gold: Jewelry Workshop Traditions at Tillya Tepe // Afghanistan: Forging Civilizations along the Silk Road (The Metropolitan Museum of Arts Symposia). New York : The Metropolitan Museum of Art. P. 78-87. 
Hsu Yiu-Kang, 2010. Archaeological Investigations of Xiongnu-Hun Cultural Connections. University of Minnesota M.A. Duluth: University of Minnesota. 243 p. Electronic text data. Mode of access: http://hdl.handle.net/11299/101715 (date of access: 12.04.2018). Title from screen.

Kat. Bonn, 2010. Gerettete Schätze Afghanistan. Die Sammlung des Nationalmuseums in Kabul. Bonn : Kunst- und Ausstellungshalle der BRD. $288 \mathrm{~S}$.

Kat. Frankfurt, 2003. Steppengold. Grabschätze der Skythen und Sarmaten am unteren Don. Frankfurt : Archäologisches Museum. 175 S.

Kat. Leoben, 2009. Das Gold der Steppe. Fürstenschätze jenseits des Alexanderreichs. Wien : Kunsthistorisches Museum. 318 S.

Kat. Schleswig, 1991. Gold der Steppe. Archäologie der Ukraine. Schleswig : Archäologisches Landesmuseum. $439 \mathrm{~S}$.

Kat. Zürich, 1993. Aus den Schatzkammern Eurasiens. Zürich : Kunsthaus Zürich. $336 \mathrm{~S}$.

Koryakova L., 2006. On the Northern Periphery of the Nomadic World: Research in the Trans-Ural Region // The Golden Deer of Eurasia. Perspectives on the Steppe Nomads of the Ancient World. New York : The Metropolitan Museum of Art. P. 102-113.

Kourkoumelis D., 2012. Transport Amphorae // The Antikythera Shipwreck, the Ship, the Treasures, the Mechanism. Exhibition catalogue. Athens : Kapon Editions. P. 208-215.

Le profane et le divin, 2008. Le profane et le divin. Arts de l'antiquité de l'Europe au Sud-Est asiatique. Fleurons du musée Barbier-Mueller. Genève : Musée Barbier-Mueller. 538 p.

LIMC III, 1986. Lexicon Iconographicum Mythologiae Classicae. T. III : Atherion - Eros. Zürich, München, Artemis-Verlag. Bd. 1. 1086 S. Bd. 2. 85 S., 741 Taf.

Loboda I. I., Puzdrovskij A. E., Zajcev Ju. P., 2002. Prunkbestattungen des 1.Jh. n. Chr. in der Nekropole Ust'-Al'ma auf der Krim. Die Ausgrabungen des Jahres 1996 // Eurasia Antiqua. Bd. 8. S. 295-346.

Marshall F. H., 1907. Catalogue of the Finger Rings, Greek, Etruscan, and Roman, in the Department of Antiquities, British Museum. London : British Museum. $258 \mathrm{p}$.

Minyaev S., 2000. The Origins of the "Geometric Style" in Hsiung nu Art // Kurgans, Ritual Sites, and Settlements: Eurasian Bronze and Iron Age (BAR International ser. 890). Oxford: Archaeopress. P. 293-303.

Mordvinceva V. I., 2001. Sarmatische Phaleren (Archäologie in Eurasien 11). Rahden/Westf. : Marie Leidorf. $100 \mathrm{~S}$.
Mordvintseva V. I., 2010. Tillya-Tepe Gold Jewellery and its Relation to the Sarmatian Animal Style of the Northern Black Sea Area // Anabasis. Vol. 1. P. 175-207.

Mordvintseva V. I., 2016. Barbarians of the North Pontic Region and Their Contacts with Centres of Antique Civilization from the $3^{\text {rd }}$ Century BCE to the mid $-3^{\text {rd }}$ Century CE (According to the Research of the Elite Burials) // Mobility in Research on the Black Sea Region. Cluj, Napoca : Mega Publishing House. P. 381-432.

Olbrycht M., 2015. Arsacid Iran and the Nomads of Central Asia - Ways of Cultural Transfer // Complexity of Interaction along the Eurasian Steppe Zone in the First Millenium CE (Bonn Contributions to Asian Archaeology 7). Bonn : Vor- und Frühgeschichtliche Archäologie, Rheinische Friedrich-Wilhelms-Universität Bonn. P. 333-390.

Patry LeidyP., 2012. Links, Missing and Otherwise: Tillya Tepe and East Asia // Afghanistan: Forging Civilizations along the Silk Road (The Metropolitan Museum of Arts Symposia). New York: The Metropolitan Museum of Arts. P. 112-121.

Peterson S., 2012. Parthian Aspects of Objects from Grave IV, Tillya Tepe, with Particular Reference to the Medallion Belt. Electronic text data. Mode of access: https://www.academia.edu/1485067/ Parthian_Aspects_of_Objects_from_Grave_IV Tillya_Tepe (date of access: 12.04.2018). Title from screen.

Pfrommer M., 1990. Untersuchungen zur Chronologie früh- und hochhellenistischen Goldschmucks (Istanbuler Forschungen 37). Tübingen : Wasmuth. $470 \mathrm{~S}$.

Pfrommer M., 1993. Metalwork from the Hellenized East. The J. Paul Getty Museum. Catalogue of the Collections. Malibu : The J. Paul Getty Museum. $256 \mathrm{p}$.

Post A., 1995. Parthische Gürtelschnallen aus Iran // Boreas. Bd. 18. S. 247-254.

Pougatchenkova G., 1978. Les trésors de DalverzineTépé. Leningrad : Éd. d'art Aurore. 98 p.

Psarras S.-K., 1995. Xiongnu Culture: Identification and Dating // Central Asiatic Journal. Vol. 39.1. P. $102-136$

Puzdrovskij A., 2013. Ust'-Al'ma: Die Siedlung und Nekropole // Die Krim. Goldene Insel im Schwarzen Meer. Griechen - Skythen - Goten. Bonn : LRV-Landesmuseum Bonn. S. 290-323.

Rahbar M., Alibaigi S., Haerinck E., Overlaet B., 2014. In Search of the Laodike Temple at Laodikeia in Media / Nahavand, Iran // Iranica Antiqua. Vol. XLIX. P. 301-329.

RostovtzeffM. I., 1931. Bronzeschnallen aus Südrussland // Prähistorische Zeitschrift. Bd. XXII. S. 46-55. 
Rudenko S. I., 1962. Die Sibirische Sammlung Peters I. (Sammlung archäologischen Quellen D3-9). Moskau ; Leningrad : Verlag der Akademie der Wissenschaften der UdSSR. 67 S.

Sarianidi V. I., 1985. Baktrisches Gold. Leningrad : Aurora-Kunstverlag. $262 \mathrm{~S}$.

Schiltz V., 1994. Die Skythen und andere Steppenvölker. München : C. H. Beck. 473 S.

Shu Takahama 高濱, 秀, 2012: 匈奴・サルマタイ 時代のユーラシア草原西部の帯飾板に ついて [On the Belt Plaques of the Western Eurasian Steppes in the Xiongnu] // 金沢大学考古学紀要 [ArchaeologyBulletin]. Kanazawa University. № 33. P. 23-34. (in Japanese).

Simonenko A. V., 2001. Bewaffnung und Kriegswesen der Sarmaten und der späten Skythen im nördlichen Schwarzmeergebiet // Eurasia Antiqua. Bd. 7. S. 187-327.

Soupault-Becquelin V., 1999. Imitatio Imperii: Les cas des plaques-boucles du style polychrome (du IIIe au IVe s. ap. J.-C.) // Germania. Bd. 77.1. P. 294-306.

Stassinopoullou E., 2012. The Golden Jewels and the Silver Vases // The Antikythera Shipwreck, the Ship, the Treasures, the Mechanism. Exhibition catalogue. Athens: Kapon Editions. P. 146-151.

The Metropolitan Museum of Art Bulletin. Spring, 1992. Volume XLIX, Number 4: Ancient Art: Gifts from the Norbert Schimmel Collection. The Metropolitan Museum of Art Publ. 65 p.

Tian Guangjin, Guo Suxin, 1980. Neimenggu Aluchaideng faxian de Xiongnu yiwu // Kaogu. № 4. P. 333-338. (in Chinese).

Treister M. Yu., 1997. New Discoveries of Sarmatian Complexes of the $1^{\text {st }}$ Century AD. A Survey of Publications in VDI// Ancient Civilizations from Scythia to Siberia. Vol. 4. P. 35-100.

Treister M., 2003. Further Thoughts about Parthian and Related Belt and Belt Plaques // Iranica antiqua. Vol. 38. P. 247-257.

Treister M., 2004a. Gold Vessels, Perfume Flasks and Pyxides from Sarmatia // Pontus and the Outside World. Studies in Black Sea History, Historiography and Archaeology (Colloquia Pontica 9). Leiden ; Boston ; Köln : E.J. Brill. P. 131-193.

Treister M., 2004b. Cloisonné- and Champlevédecoration in the Gold Work of the Late Hellenistic - Early Imperial Periods // Acta Archaeologica. Vol. 75.2. P. 189-219.

Treister M., 2005. On a Vessel with Figured Friezes from a Private Collection, on Burials in Kosika and Once More on the "Ampsalakos School" // Ancient Civilisations from Scythia to Siberia. Vol. 11.3-4. P. 199-255.
Treister M. Yu., Yatsenko S. A., 1998. About the Centres of manufacture of Certain Series of HorseHarness Roundels in 'Gold-Turquoise Animal Style' of the $1^{\text {st }}-2^{\text {nd }}$ Centuries AD // Silk Road Art and Archaeology. Vol. 5. P. 51-106.

Tselekas P., 2012. The coins // The Antikythera Shipwreck, the Ship, the Treasures, the Mechanism. Exhibition catalogue. Athens : Kapon Editions. P. 216-226.

Werness H. B., 2003. The Continum Encyclopedia of Animal Symbolism in Art. New York ; London : Continuum International Publishing Group. $400 \mathrm{p}$.

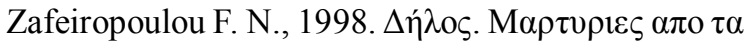

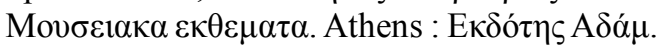
303 p. (in Greek).

Zimmermann J.-L., 1991. Ancient Art from the BarbierMueller Museum. New York : Harry N. Abrams Inc. $183 \mathrm{p}$.

\section{REFERENCES}

Abdullaev K., 2011. Parthian Morifs in the Wallpainting of Nakhsheb (Erkurgan and its Vicinities). Un impaziente desiderio di scorrere il mondo. Studi in onore di Antonio Invernizzi per il suo settantesimo compleanno (Monografie di Mesopotamia XIV). Firenze, Casa Editrice "LeLettere", pp. 309-320. (in Russian).

Abramova M.P., 1998. Chronological Peculiarities of the North-Caucasian Buckles of the First Centuries AD. Materialy po arkheologii $i$ etnografii Tavrii, iss. VI. Simferopol, pp. 209-229. (in Russian).

Artamonov M.I., 1973. The Treasures of Saka. Moscow, Iskusstvo Publ. 280 p. (in Russian).

Archaeological Heritage, 2013. Archaeological Heritage of the Volgograd Region. To the $100^{\text {th }}$ Anniversary of the Volgograd Local Lore Museum. Volgograd, Izdatel' Publ. 288 p. (in Russian).

Bespalyj E.I., 1992. A Burial-mound of the Sarmatian Period near the City of Azov. Sovetskaja arkheologiya, no. 1, pp. 175-190. (in Russian).

Vinogradov Yu.G., 1994. An Eassay of Military-Political History of the Sarmatians in the $1^{\text {st }}$ Century AD. Journal of Ancient History, no. 2, pp. 151-170. (in Russian).

Vlaskin M.V., 1989. Gold Zoomorphic Buckles from the Kurgan Necropolis near Novyj Farmstead. Istoriko-archeologicheskie issledovaniya $v$ g. Azove i na Nizhnem Donu v 1988 godu: (tez. dokl. $k$ seminaru). Azov, Azov History, Archaeology and Palaeontology MuseumReserve, pp. 29-37. (in Russian). 
Glebov V.P., 2016. Buckles with Zoomorphic Images in the Early Sarmatian Culture of the Lower Don Basin. Konstantin Fedorovich Smirnov $i$ sovremennye problemy sarmatskoj arkheologii: materialy IX Mezhdunar. nauch. konf. "Problemy sarmatskoj arkheologii $i$ istorii», posvjashch. 100-letiju so dnja rozhdenija Konstantina Fedorovicha Smirnova. Orenburg, Orenburg State Pedagogical Univ. Publ., pp. 6979. (in Russian).

Gordin I.A., 1989. A Report of the Archaeological Excavations of the Burial-mounds near the Village of Chaltyr ' and Kurgan Necropolis "Khapry" in the Zone of Construction of the Irrigation Area of the Myasnikovskij District of the Rostov Region in 1988. Azov. Arkhiv IA RAN, no. R-1, files no. 12939-12940. (in Russian).

Gushchina I.I., Zasetskaya I.P., 1994. "Golden Cemetery" of the Roman Period in the Kuban Area. St. Petersburg, Farn Publ. 172 p. (in Russian).

DBK, 1854. Antiquites du Bosphore cimmerien, conservees au musee impérial de l'Ermitage. St.-Pétersbourg, Imprimerie de l'Académie Impériale des Sciences, vol. 1. 279 p., vol. 2. 339 p., vol. 3.236 p. 86 pls. (in Russian / French).

Dvornichenko V.V., Fedorov-Davydov G.A., 1989. Sites of the Sarmatian Aristocracy in the Lower Volga Basin. Sokrovishcha sarmatskikh vozhdej $i$ drevnie goroda Povolzh'ja. Moscow, Nauka Publ., pp. 5-13. (in Russian).

Dvornichenko V.V., Fedorov-Davydov G.A., 1993. A Burial of Sarmatian Skeptuchos of the $1^{\text {st }}$ Century AD near the Village of Kosika of the Astrakhan Region. Journal of Ancient History, no. 3, pp. 141-179. (in Russian).

The Earliest States, 1985. The Earliest States of the Caucasus and Central Asia (Archaeology of the USSR). Moscow, Nauka Publ. 496 p. (in Russian).

Zasetskaya I.P., 1979. Sauromatian and Sarmatian Burials of the Nikol'skoe Cemetery in the Lower Volga Region. Trudy Gosudarstvennogo Ermitazha [Transactions of the State Hermitage Museum], iss. XX, pp. 87-113. (in Russian).

Zasetskaya I.P., 2012a. Images of Griffins and "Gryphs" in Sarmatian Animal Style. Zoloto, kon", chelovek: sb. st. $k$ 60-letiju Aleksandra Vladimirovicha Simonenko. Kiev, KNT Publ., pp. 353-383. (in Russian).

Zasetskaya I.P., 2012b. The Image of a Wolf in the 1st Century AD Sarmatian Art. Voyager: mir $i$ chelovek: teoret. i nauch.-metod. zhurn., iss. 3. Samara, pp. 63-73. (in Russian).

Zasetskaya I.P., 2013. The Meaning of the Items of Sarmatian Polychrome Animal Style in the Burial
Rite of the $1^{\text {st }}$ Century AD. Arkheologicheskij sbornik Gosudarstvennogo Ermitazha [Archaeological Papers], iss. 39, pp. 138-147. (in Russian).

Il'yukov L.S., Vlaskin M.V., 1992. The Sarmatians of the Interfluve of the Sal and Manych Rivers. Rostov-on-Don, Rostov-on-Don State Univ. Publ. 288 p. (in Russian).

Kareisha D.V., 1844. Excavations of the Burial-mounds near Kerch and Taman in 1842 and in early 1843. Zapiski Odesskogo Obshchestva istorii $i$ drevnostej, vol. 1, pp. 609-620. (in Russian).

Kat. Novocherkassk, 1981. Novocherkassk Museum of the History of Don Cossaks. The Catalogue of the Exhibition of New Acquisitions of the Archaeological Department (1970-1980). Novocherskassk, Museum of the History of Don Cossaks. 80 p. (in Russian).

Kat. St. Petersburg, 2004. Iran in the Hermitage. The Formation of Collection. St. Petersburg, Slavija Publ. 255 p. (in Russian).

Kat. St. Petersburg, 2008. The Treasures of the Sarmatians. Exhibition Catalogue. To the $100^{\text {th }}$ Birthday of B.B. Piotrovskij. St. Petersburg, Azov, Azov HistoricalArchaeological and Paleoontological Reserve Publ. 176 p. (in Russian).

Klepikov V.M., 2002. The Sarmatians of the Lower Volga Basin in the $4^{\text {th }}-3^{\text {rd }}$ Centuries $B C$. Volgograd, Volgograd State University Publ. 216 p. (in Russian).

Korol'kova E.F., 2006. The Animal Style of Eurasia. The Art of the Tribes of the Lower Volga and South Urals in the Scythian Period $\left(7^{\text {th }}-4^{\text {th }}\right.$ Centuries $B C)$. St. Petersburg, Petersburgskoe vostokovedenie. 272 p. (in Russian).

Maksimenko V.E., 1998. The Sarmatians on the Don River (Archaeology and the Problems of the Ethnic History) (Donskie drevnosti 6). Azov, Azov Local Lore Museum Publ. 304 p. (in Russian).

Malashev V.Yu., Dtsuev F.S., 2016. Gala Horse-Harness Setes of the $3^{\text {rd }}$ Century AD from Beslan Cemetery and the Problem of Formation of the Alanian Culture of the Northern Caucasus. Malashev V.Yu. Pamyatniki srednesarmatskoj kul'tury severokavkazskikh stepej $i$ ikh traditsii $v$ kurgannykh mogil'nikakh SeveroVostochnogo Kavkaza vtoroj poloviny $2^{\text {nd }}-$ serediny $5^{\text {th }}$ v. n.e. Moscow, Institute of Archaeology, Russian Academy of Sciences, pp. 160-177.

Mamontov V.I., 2000. Ancient Population of the Left Bank of the Don River (after the Materials of Pervomajskij VII Necropolis). Volgograd, Volgograd State Univ. Publ. 145 p. (in Russian). 
Matyushchenko V.I., Tataurova L.V., 1997. Burialground Sidorovka in the Irtysh Basin of Omsk Region. Novosibirsk, Nauka Publ. 197 p. (in Russian).

Minyaev S.S., 1995. The Newest Finds of Artistic Bronzes and the Problem of Establishment of the Geometric Style in the Hsiung nu Art. Arkheologicheskie vesti, iss. 4, pp. 123-136. (in Russian).

Mordvintseva V.I., 2003. The Polychrome Animal Style. Simferopol, Universum Publ. 216 p. (in Russian).

Mordvintseva V.I., 2007. Sarmatian Polychrome Animal Style. Mordvintseva V.I., Treister M.Yu. Items of Toreutics and Jewelry in the North Pontic Area. $2^{\text {nd }}$ Century $B C-2^{\text {nd }}$ Century AD. Vol. I. Simferopol, Bonn, Tarpan, pp. 195-244. (in Russian).

Mordvintseva V.I., Mys'kov E.P., 1999. Burial-mounds of the Sarmatian Elite near the Settlement Oktyabr'skij. Arkheologicheskie vesti, iss. 6, pp. 179-191. (in Russian).

Mordvintseva V.I., Treister M.Yu., 2007. Items of Toreutics and Jewelry in the North Pontic Area. $2^{\text {nd }}$ Century $B C-2^{\text {nd }}$ Century $A D$. In 3 vols. Vol. 2. Simferopol, Bonn, Tarpan. 255 p. (in Russian).

Moshkova M.G., 1960. Early Sarmatian Bronze Buckles. Drevnosti Nizhnego Povolzh'ya. Vol. II (Itogi rabot Stalingradskoj arkheologicheskoj ekspeditsii) (Materialy i issledovaniya po arkheologii SSSR.Vol. 78). Moscow, Nauka Publ., pp. 293-307. (in Russian).

Rakhmanova S.I., 1990. The Amulet from Erkurgan. Arkheologiya Srednej Azii: tez. dokl. Tashkent, Tashkent State University, p. 83. (in Russian).

Simonenko A.V., 2015. Sarmatian Horsemen of the North Pontic Area. $2^{\text {nd }}$ ed. Kiev, Oleg Filyuk Publ. 466 p. (in Russian).

Simonenko A.V., Lobaj B.I., 1991. The Sarmatians of the North-Weszern Pontic Area in the $1^{\text {st }}$ Century AD. Kiev, Naukova dumka Publ. 108 p. (in Russian).

Skripkin A.S., 1990. Asian Sarmatia. Problems of Chronology and its Historical Aspect. Saratov, Saratov Univ. Publ. 303 p. (in Russian).

Skripkin A.S., 2000. New Aspects in the Study of the History of the Material Culture of the Sarmatians. Nizhnevolzhskij arheologicheskij vestnik [The Lower Volga Archaeological Bulletin], iss. 3, pp. 17-40. (in Russian).

Skripkin A.S., 2006. To the Problem of Correlation of the Early- and Middle-Sarmatian Cultures. Rannesarmatskaya i srednesarmatskaya kul tury: problemy sootnosheniya, iss. 1. Volgograd, Volgograd Scientific Publ., pp. 5-27. (in Russian).
Smirnov A.P., 1940. New Sarmatian Necropolis in Voronezh Region. Vestnik drevnei istorii [Journal of Ancient History], nos. 3-4, pp. 363366. (in Russian).

Spitsyn A.A., 1909. The Phalerae of South Russia. Izvestiya imperatorskoj arkheologicheskoj komissii [Bulletinde la Commission impériale archéologique], iss. 29, pp. 18-53. (in Russian).

Sulejmanov R.Kh., 2000. Ancient Nakhshab. Tashkent, Fan Publ. 338 p. (in Russian).

Tolstoj I.I., Kondakov N.P., 1889. Scytho-Sarmatian Antiquities (Russian Antiquities in the Art Monuments.Vol. 2). St. Petersburg, Printing House of the Ministry of Railways. $161 \mathrm{p}$. (in Russian).

Treister M.Yu., 1994. Sarmatian School of the Artistic Toreutics (To the Find of the Table Set from Kosika). Vestnik drevnei istorii [Journal of Ancient History], no. 3, pp. 172-203. (in Russian).

Treister M.Yu., 2007a. Types of attached lamellar Cloisons, Shape, Material and Color of the Inlays. Mordvintseva V.I., Treister M.Yu. Items of Toreutics and Jewelry in the North Pontic Area. $2^{\text {nd }}$ Century BC $-2^{\text {nd }}$ Century AD. Vol. I. Simferopol, Bonn, Tarpan, pp. 272-287. (in Russian).

Treister M.Yu., 2007б. Cloisonné. Mordvintseva V.I., Treister M.Yu. Items of Toreutics and Jewelry in the North Pontic Area. $2^{\text {nd }}$ Century BC$2^{\text {nd }}$ Century AD. Vol. I. Simferopol, Bonn, Tarpan, pp. 288-294. (in Russian).

Treister M.Yu., 2007в. Inlays of Gems (with the Exception of Finger Rings). Mordvintseva V.I., Treister M.Yu. Items of Toreutics and Jewelry in the North Pontic Area. $2^{\text {nd }}$ Century BC$2^{\text {nd }}$ Century AD. Vol. I. Simferopol, Bonn, Tarpan, pp. 295-305. (in Russian).

Treister M.Yu., 2015. A Warrior in Armor, crowned by Nike, in the Monumental Art of the Bosporus in the First Centuries AD (Who is depicted on the Reliefs from Pantikapaion and Tanais?). $S$ Mitridata duet veter. Bospor i Prichernomor'je $v$ antichnosti. K 70-letiju V.P. Tolstikova. Moscow, Dmitry Pozharsky University, pp. 288304. (in Russian).

Tuallagov A.A., 2013. The Alans and Some Data of the Epigraphic Monuments. Izvestiya SeveroOsetinskogo Instituta gumanitarnykh $i$ sotsial'nykh issledovanij, iss. 9 (48), pp. 20-32. (in Russian).

Tuallagov A.A., 2014. Alans of the Daryal area and the Transcaucasian Raids of the $1^{\text {st }}$ $2^{\text {nd }}$ Centuries AD. Vladikavkaz, NorthOssetian Institute of Humanitarian and Social Studies of the Vladikavkaz Scientific Center 
of the Russian Academy of Sciences and Republic of North Ossetia-Alania Publ. 230 p. (in Russian).

Shtein V.F., 1968. The Buckle with the Images of Hedgehogs from the Siberian Collection of the Hermitage. Sovetskaja arkheologiya, no. 2, pp. 269-272. (in Russian).

Yatsenko S.A., 2000. On alleged "Bactrian" Items of Jewelry in Sarmatia in the $1^{\text {st }}-2^{\text {nd }}$ Centuries AD. The Lower Volga Archaeological Bulletin, no. 3, pp. 172-185. (in Russian).

Abdullaev K.A., 2008. Bactrian Gold Buckle with the Contest Between a Hero and a Centaur (Herakles and Nessos?). Parthica, vol. 10, pp. 135-149.

Baumer C., 2012. The History of Central Asia: The Age of the Steppe Warriors. New York, I.B. Tauris \& Co. Ltd. 384 p.

Bernard P., Bopearachchi O., 2002. Deux bracelets grecs avec inscriptions grecques trouvés dans l'Asie centrale hellénisée. Journal des savants, pp. 237-278.

Boardman J., 2010. The Relief Plaques of Eastern Eurasia and China. The 'Ordos Bronzes', Peter the Great's Treasure, and their kin (Beazley Archive Occasional Paper). Oxford, Archaeopress. 103 p.

Boardman J. 2012. Tillya Tepe: Echoes of Greece and China. Afghanistan: Forging Civilizations along the Silk Road (The Metropolitan Museum of Arts Symposia). New York, The Metropolitan Museum of Art, pp, 102-111.

Boardman J., 2015. The Greeks in Asia. London, Thames and Hudson Ltd. $240 \mathrm{p}$.

Brosseder U., 2011. Belt Plaques as an Indicator of East-West Relations in the Eurasian Steppe at the Turn of the Millennia. Xiongnu Archaeology. Multidisciplinary Perspectives of the First Steppe Empire in Inner Asia (Bonn Contributions to Asian Archaeology, 5). Bonn, Vor- und Frühgeschichtliche Archäologie, Rheinische Friedrich-Wilhelms-Universität Bonn, pp. 349-424.

Bunker E.C., 1997. Ancient Bronzes of the Eastern Eurasian Steppes from the Arthur M. Sackler Collection. New York, Arthur M. Sackler Foundation. 401 p.

Bunker E.C., Watt Y.C.Y., Zhisun Sun, 2002. Nomadic Art of the Eastern Eurasian Steppes. The Eugene V. Thaw and Other New York Collections. New York, New Haven, London, Yale University Press. 320 p.

Cat. Daoulas, 1995. Entre Asie et Europe. L'or des Sarmates. Nomades des steppes dans l'antiquité. 17 juin - 29 octobre 1995. Abbaye de Daoulas, Centre culturel Abbaye de Daoulas. $141 \mathrm{p}$.
Cat. Los Angeles, 1981. Moorey P.R.S., Bunker E.C., Porada E., Markoe G. Ancient Bronzes, Ceramics and Seals. The Nasli M. Heeramaneck Collection of Ancient Near Eastern, Central Asiatic, and European Art. Los Angeles County Museum. Los Angeles, Los Angeles County Museum of Art. $271 \mathrm{p}$.

Cat. Milan, 1995. Tesori delle Steppe. Cimmeri, Sciti, Sarmati, Unni, Avari e Cazari. Milano, Galleria Ottavo Piano, La Rinascente. 210 p.

Cat. New York, 1990. Glories of the Past. Ancient Art from the Shelby White and Leon Levy Collection. The Metropolitan Museum of Art. New York, The Metropolitan Museum of Art. 280 p.

Cat. New York, 2000. The Year One. Art of the Ancient World. East and West. New York, The Metropolitan Museum of Art.192 p.

Cat. Paris, 1961. Sept mille ans d'art en Iran. Paris, Les Presses artistiques. 209 p.

Cat. Paris, 2000. L'Asie des steppes d'Alexandre le Grand à Gengis Khån. Paris, Reìunion des museìes nationaux. 202 p.

Cat. Paris, 2001. L'or des Amazones. Paris, Editions Findakly/Paris musées. 300 p.

Cat. Rome, 2005. I Tesori della steppa di Astrakhan. Milano, Mondadori Electa. 183 p.

Cat. Tokyo, 1991. The Treasures of Nomadic Tribes in South Russia. Tokyo, Ancient Orient Museum. $178 \mathrm{p}$.

Cat. Washington, 1995. So J.F., Bunker E.C. Traders and Raiders on China's Northern Frontier. Seattle, London, Smithsonian Institution, in association with University of Washington Press. 203 p.

Collon D., 1995. British Museum. Ancient Near Eastern Art. London, University of California Press. 247 p.

Curtis V.S., 2001. Parthian Belts and Belt Plaques. Iranica antiqua, vol. XXXVI, pp. 299-327.

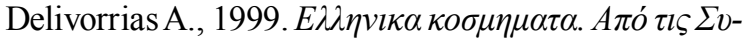

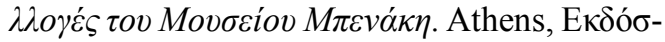

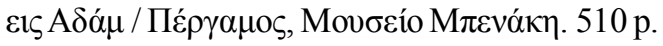
(in Greek).

Di Cosmo N., 1999. The Northern Frontier in PreImperial China. The Cambridge History of Ancient China. Cambridge, Cambridge University Press, pp. 885-966.

Dvornitchenko V.V., Fedorov-Davydov G.A., 1994. Trésors des tombes de l'aristocratie sarmate au nord de la Caspienne. Les dossiers d'archéologie, no. 194, pp. 66-75.

Farkas A., 1973. Sarmatian Roundels and Sarmatian Art. The Metropolitan Museum of Art Journal, vol. 8, pp. 77-88.

Fedorov-Davydov G.A., 2001. The Silk Road and the Cities of the Golden Horde. Berkeley, Zinat Press. 189 p. 
Ghirshman R. 1962. Iran. Parther und Sasaniden. München, C.H. Beck. 404 S.

Ghirshman R., 1969. Disque en bronze a decor ternaire. Forschungen zur Kunst Asiens: In memoriam Kurt Erdmann. Istanbul: Istanbul Üniversitesi Edebiyat Fakültesi, Türk ve Isläm Sanati Kürsüsü, pp. 9-17.

Ghirshman R., 1979. La ceinture en Iran. Iranica antiqua, vol. 14, pp. 166-196.

Gift..., 1985. Gift of Keith P. Smith 1985. 180. URL: https://www.clevelandart.org/art/1985.180? $\mathrm{f} \% 5 \mathrm{~B} 0 \% 5 \mathrm{D}=$ field_art_credit_line $\% 3 \mathrm{AGift}$ $\% 20$ of $\% 20$ Keith\%20P.\%20Smith. (date of access 12.04.2018).

Hackens T., Lévy E., 1965. Trésor hellénistique trouvé à Délos en 1964. Bulletin de correspondence hellénique, vol. 89, pp. 503-566.

Herzfeld E.B. 1928. The Hoard of the Karen Pahlavs. Burlington Magazine, vol. 53, pp. 21-27.

Hickman J., 2012. Bactrian Gold: Jewelry Workshop Traditions at Tillya Tepe. Afghanistan: Forging Civilizations along the Silk Road (The Metropolitan Museum of Arts Symposia). New York, The Metropolitan Museum of Art, pp. 78-87.

Hsu Yiu-Kang, 2010. Archaeological Investigations of Xiongnu-Hun Cultural Connections. University of Minnesota M.A. Duluth, University of Minnesota. 243 p. URL:http://hdl. handle.net/11299/101715. (date of access 12.04.2018).

Kat. Bonn, 2010. Gerettete Schätze Afghanistan. Die Sammlung des Nationalmuseums in Kabul. Bonn, Kunst- und Ausstellungshalle der BRD. 288 p.

Kat. Frankfurt, 2003. Steppengold. Grabschätze der Skythen und Sarmaten am unteren Don. Frankfurt, Archäologisches Museum. 175 p.

Kat. Leoben, 2009. Das Gold der Steppe. Fürstenschätze jenseits des Alexanderreichs. Wien, Kunsthistorisches Museum. 318 p.

Kat. Schleswig, 1991. Gold der Steppe. Archäologie der Ukraine. Schleswig, Archäologisches Landesmuseum. 439 p.

Kat. Zürich, 1993. Aus den Schatzkammern Eurasiens. Zürich, Kunsthaus Zürich. 336 p.

Koryakova L., 2006. On the Northern Periphery of the Nomadic World: Research in the Trans-Ural Region. The Golden Deer of Eurasia. Perspectives on the Steppe Nomads of the Ancient World. New York, The Metropolitan Museum of Art, pp. 102-113.

Kourkoumelis D., 2012. Transport Amphorae. The Antikythera Shipwreck, the Ship, the Treasures, the Mechanism. Exhibition catalogue. Athens, Kapon Editions, pp. 208-215.

Le profane et le divin, 2008. Le profane et le divin. Arts de l'antiquité de l'Europe au Sud-Est asiatique. Fleurons du musée Barbier-Mueller. Genève, Musée Barbier-Mueller. 538 p.

LIMC III, 1986. Lexicon Iconographicum Mythologiae Classicae. Vol. III: Atherion - Eros. Zürich, München, Artemis-Verlag. Bd. 1. 1086 p. Bd. 2. 85 p., 741 Taf.

Loboda I.I., Puzdrovskij A.E., Zajcev Ju.P., 2002. Prunkbestattungen des 1.Jh. n. Chr. in der Nekropole Ust'-Al'ma auf der Krim. Die Ausgrabungen des Jahres 1996. Eurasia Antiqua, Bd. 8, pp. 295-346.

Marshall F.H., 1907. Catalogue of the Finger Rings, Greek, Etruscan, and Roman, in the Department of Antiquities, British Museum. London, British Museum. 258 p.

Minyaev S., 2000. The Origins of the "Geometric Style" in Hsiung nu Art. Kurgans, Ritual Sites, and Settlements: Eurasian Bronze and Iron Age (BAR International ser. 890). Oxford, Archaeopress, pp. 293-303.

Mordvinceva V.I., 2001. Sarmatische Phaleren (Archäologie in Eurasien 11). Rahden/Westf., Marie Leidorf. $100 \mathrm{p}$.

Mordvintseva V.I., 2010. Tillya-Tepe Gold Jewellery and its Relation to the Sarmatian Animal Style of the Northern Black Sea Area. Anabasis, vol. 1, pp. 175-207.

Mordvintseva V.I., 2016.Barbarians of the North Pontic Region and Their Contacts with Centres of Antique Civilization from the $3^{\text {rd }}$ Century BCE to the mid $-3^{\text {rd }}$ Century CE (According to the Research of the Elite Burials). Mobility in Research on the Black Sea Region. Cluj, Napoca, Mega Publishing House, pp. 381-432.

Olbrycht M., 2015. Arsacid Iran and the Nomads of Central Asia - Ways of Cultural Transfer. Complexity of Interaction along the Eurasian Steppe Zone in the First Millenium CE (Bonn Contributions to Asian Archaeology 7). Bonn, Vor- und Frühgeschichtliche Archäologie, Rheinische Friedrich-Wilhelms-Universität Bonn, pp. 333-390.

Patry Leidy P., 2012. Links, Missing and Otherwise: Tillya Tepe and East Asia. Afghanistan: Forging Civilizations along the Silk Road (The Metropolitan Museum of Arts Symposia). New York, The Metropolitan Museum of Arts, pp. 112-121.

Peterson S., 2012. Parthian Aspects of Objects from Grave IV, Tillya Tepe, with Particular Reference to the Medallion Belt. URL: https://www. academia.edu/1485067/Parthian_Aspects_ of_Objects_from_Grave_IV_Tillya_Tepe (date of access 12.04.2018).

Pfrommer M., 1990. Untersuchungen zur Chronologie früh- und hochhellenistischen Goldschmucks 
M.Yu. Treister. A Precious Belt Set from the Nomadic Elite Burial near the Village of Kosika

(Istanbuler Forschungen 37). Tübingen, Wasmuth. $470 \mathrm{p}$.

Pfrommer M., 1993. Metalwork from the Hellenized East. The J. Paul Getty Museum. Catalogue of the Collections. Malibu, The J. Paul Getty Museum. 256 p.

Post A., 1995. Parthische Gürtelschnallen aus Iran. Boreas, Bd. 18, pp. 247-254.

Pougatchenkova G., 1978. Les trésors de DalverzineTépé. Leningrad, Éd. d'art Aurore. 98 p.

Psarras S.-K., 1995. Xiongnu Culture: Identification and Dating. Central Asiatic Journal, vol. 39.1, pp. 102-136.

Puzdrovskij A., 2013. Ust'-Al'ma: Die Siedlung und Nekropole. Die Krim. Goldene Insel im Schwarzen Meer. Griechen - Skythen - Goten. Bonn, LRV-Landesmuseum Bonn, pp. 290-323.

Rahbar M., Alibaigi S., Haerinck E., Overlaet B., 2014. In Search of the Laodike Temple at Laodikeia in Media / Nahavand, Iran. Iranica Antiqua, vol. XLIX, pp. 301-329.

Rostovtzeff M.I., 1931. Bronzeschnallen aus Südrussland. Prähistorische Zeitschrift, Bd. XXII, pp. 46-55.

Rudenko S.I., 1962. Die Sibirische Sammlung Peters I. (Sammlung archäologischen Quellen D3-9). Moskau, Leningrad, Verlag der Akademie der Wissenschaften der UdSSR. 67 p.

Sarianidi V.I., 1985. Baktrisches Gold. Leningrad, Aurora-Kunstverlag. 262 p.

Schiltz V., 1994. Die Skythen und andere Steppenvölker. München, C.H. Beck. 473 p.

Shu Takahama高濱, 秀, 2012: 匈奴・サルマタイ 時代のユーラシア草原西部の帯飾板に ついて [On the Belt Plaques of the Western Eurasian Steppes in the Xiongnu]. 金沢大学考古学紀要 [Archaeology Bulletin]. Kanazawa University, no. 33, pp. 23-34. (in Japanese).

Simonenko A.V., 2001. Bewaffnung und Kriegswesen der Sarmaten und der späten Skythen im nördlichen Schwarzmeergebiet. Eurasia Antiqua, Bd. 7, pp. 187-327.

Soupault-Becquelin V., 1999. Imitatio Imperii: Les cas des plaques-boucles du style polychrome (du IIIe au IVe s. ap. J.-C.). Germania, Bd. 77.1, pp. 294-306.

Stassinopoullou E., 2012. The Golden Jewels and the Silver Vases. The Antikythera Shipwreck, the
Ship, the Treasures, the Mechanism.Exhibition catalogue. Athens, Kapon Editions, pp. 146-151.

The Metropolitan Museum of Art Bulletin. Spring, 1992, Volume XLIX. Number 4. Ancient Art: Gifts from the Norbert Schimmel Collection. The Metropolitan Museum of Art Publ. 65 p.

Tian Guangjin, Guo Suxin, 1980. Neimenggu Aluchaideng faxian de Xiongnu yiwu. Kaogu, no. 4, pp. 333-338. (in Chinese).

Treister M.Yu., 1997. New Discoveries of Sarmatian Complexes of the $1^{\text {st }}$ Century AD. A Survey of Publications in VDI. Ancient Civilizations from Scythia to Siberia, vol. 4, pp. 35-100.

Treister M., 2003. Further Thoughts about Parthian and Related Belt and Belt Plaques. Iranica antiqua, vol. 38, pp. 247-257.

Treister M., 2004a. Gold Vessels, Perfume Flasks and Pyxides from Sarmatia. Pontus and the Outside World. Studies in Black Sea History, Historiography and Archaeology (Colloquia Pontica 9). Leiden, Boston, Köln, E.J. Brill, pp. 131-193.

Treister M., 2004b. Cloisonné-and Champlevédecoration in the Gold Work of the Late Hellenistic - Early Imperial Periods. Acta Archaeologica, vol. 75.2, pp. 189-219.

Treister M., 2005. On a Vessel with Figured Friezes from a Private Collection, on Burials in Kosika and Once More on the "Ampsalakos School". Ancient Civilisations from Scythia to Siberia, vol. 11.3-4, pp. 199-255.

Treister M.Yu., Yatsenko S.A., 1998. About the Centres of manufacture of Certain Series of HorseHarness Roundels in 'Gold-Turquoise Animal Style' of the $1^{\text {st }}-2^{\text {nd }}$ Centuries AD. Silk Road Art and Archaeology, vol. 5, pp. 51-106.

Tselekas P., 2012. The coins. The Antikythera Shipwreck, the Ship, the Treasures, the Mechanism. Exhibition catalogue. Athens, Kapon Editions, pp. 216-226.

Werness H.B., 2003. The Continum Encyclopedia of Animal Symbolism in Art. New York, London, Continuum International Publishing Group. 400 p.

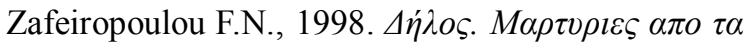

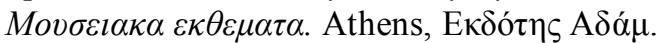
303 p. (in Greek).

Zimmermann J.-L., 1991. Ancient Art from the BarbierMueller Museum. New York, Harry N. Abrams Inc. $183 \mathrm{p}$. 
М.Ю. Трейстер. Драгоценный поясной набор из элитного погребения кочевника у с. Косика

\section{Information about the Author}

Mikhail Yu. Treister, Doctor of Sciences (History), Researcher, German Archaeological Institute, Podbielskiallee,69-71, 14195 Berlin, Germany, mikhail.treister@dainst.de, mikhailtreister@yahoo.de.

\section{Информация об авторе}

Михаил Юрьевич Трейстер, доктор исторических наук, научный сотрудник, Германский археологический институт, Podbielskiallee, 69-71, 14195 г. Берлин, Германия, mikhail.treister@dainst.de, mikhailtreister@yahoo.de. 